\title{
Systems Study for Improving Gas Turbine Performance for Coal/IGCC Application
}

\section{Final Report}

Tasks 1-6

January 1, 2004 to September 30, 2005

Submitted To: US Department of Energy

National Energy Technology Laboratory

Morgantown, WV 26507-0880

Submitted By: GE Energy

Schenectady, NY. 12345

December 16, 2005

DOE Cooperative Agreement No. DE-FC26-03NT41889 


\section{DISCLAIMER}

This report was prepared as an account of work sponsored by an agency of the United States Government. Neither the United States Government nor any agency thereof, nor any of their employees, makes any warranty, express or implied, or assumes any legal liability or responsibility for the accuracy, completeness, or usefulness of any information, apparatus, product, or process disclosed, or represents that its use would not infringe privately owned rights. Reference herein to any specific commercial product, process, or service by trade name, trademark, manufacturer, or otherwise does not necessarily constitute or imply its endorsement, recommendation, or favoring by the United States Government or any agency thereof. The views and opinions of authors expressed herein do not necessarily state or reflect those of the United States Government or any agency thereof. 


\begin{abstract}
This study identifies vital gas turbine (GT) parameters and quantifies their influence in meeting the DOE Turbine Program overall Integrated Gasification Combined Cycle (IGCC) plant goals of $50 \%$ net HHV efficiency, $\$ 1000 / \mathrm{kW}$ capital cost, and low emissions. The project analytically evaluates GE advanced F class air cooled technology level gas turbine conceptual cycle designs and determines their influence on IGCC plant level performance including impact of Carbon capture. This report summarizes the work accomplished in each of the following six Tasks.

Task 1.0 - Overall IGCC Plant Level Requirements Identification: Plant level requirements were identified, and compared with DOE's IGCC Goal of achieving 50\% Net HHV Efficiency and $\$ 1000 / \mathrm{KW}$ by the Year 2008, through use of a Six Sigma Quality Functional Deployment (QFD) Tool. This analysis resulted in 7 GT System Level Parameters as the most significant.
\end{abstract}

Task 2.0 - Requirements Prioritization/Flow-Down to GT Subsystem Level: GT requirements were identified, analyzed and prioritized relative to achieving plant level goals, and compared with the flow down of power island goals through use of a Six Sigma QFD Tool. This analysis resulted in 11 GT Cycle Design Parameters being selected as the most significant.

Task 3.0 - IGCC Conceptual System Analysis: A Baseline IGCC Plant configuration was chosen, and an IGCC simulation analysis model was constructed, validated against published performance data and then optimized by including air extraction heat recovery and GE steam turbine model. Baseline IGCC based on GE 207FA+e gas turbine combined cycle has net HHV efficiency of $40.5 \%$ and net output nominally of 526 Megawatts at NOx emission level of 15 ppmvd@15\% corrected O2. 18 advanced F technology GT cycle design options were developed to provide performance targets with increased output and/or efficiency with low NOx emissions.

Task 4.0 - Gas Turbine Cycle Options vs. Requirements Evaluation: Influence coefficients on 4 key IGCC plant level parameters (IGCC Net Efficiency, IGCC Net Output, GT Output, NOx Emissions) of $11 \mathrm{GT}$ identified cycle parameters were determined. Results indicate that IGCC net efficiency HHV gains up to 2.8 pts $(40.5 \%$ to $43.3 \%)$ and IGCC net output gains up to $35 \%$ are possible due to improvements in GT technology alone with single digit NOx emission levels.

Task 5.0 - Recommendations for GT Technical Improvements: A trade off analysis was conducted utilizing the performance results of 18 gas turbine (GT) conceptual designs, and three most promising GT candidates are recommended. A roadmap for turbine technology development is proposed for future coal based IGCC power plants.

Task 6.0 - Determine Carbon Capture Impact on IGCC Plant Level Performance: A gas turbine performance model for high Hydrogen fuel gas turbine was created and integrated to an IGCC system performance model, which also included newly created models for moisturized syngas, gas shift and $\mathrm{CO} 2$ removal subsystems. This performance model was analyzed for two gas turbine technology based subsystems each with two Carbon removal design options of $85 \%$ and $88 \%$ respectively. The results show larger IGCC performance penalty for gas turbine designs with higher firing temperature and higher Carbon removal. 


\section{TABLE OF CONTENTS}

Disclaimer i

$\begin{array}{lll}\text { Abstract } & \text { ii }\end{array}$

Figures and Tables $\quad$ iv, v

$\begin{array}{ll}\text { Introduction } & 1\end{array}$

Executive Summary $\quad 2$

$\begin{array}{ll}\text { Experimental } & 4\end{array}$

Results and Discussion $\quad 6$

$\begin{array}{ll}\text { Conclusions } & 35\end{array}$

$\begin{array}{ll}\text { References } & 38\end{array}$

List of Acronyms and Abbreviations

Cooperative Agreement No: $\quad$ iii 


\section{Figures and Tables}

Figures:

Figure 1 - Matrix for Plant Level QFD

Figure 2 - Pareto for Plant Level QFD

Figure 3 - Matrix for Gas Turbine QFD

Figure 4 - Pareto for Gas Turbine QFD

Figure 5 - Baseline IGCC Plant Configuration and Performance

Figure 6 - Integrated IGCC Simulation Analysis Model of Baseline IGCC Plant

Figure 7 - Gas Turbine Configuration Options

Figure 8 - IGCC Plant Performance of GT Design Options

Figure 9 - IGCC Net Efficiency vs. GT Specific Output for various GT options

Figure 10 - IGCC Specific Output vs. GT Specific Output for various GT Options

Figure 11: IGCC Net Efficiency vs. IGCC Specific Output for various GT options

Figure 12: Turbine Technology Roadmap for future coal-based IGCC

Figure 13: Simplified IGCC Cycle with CO2 Capture

Figure 14: Carbon Removal From O2 Blown IGCC Power Plant

Figure 15: Shift conversion rate vs. \% Saturation of Syngas

Figure 16: Auxiliary Power Consumed vs. \% CO2 Removal in AGR Unit

Figure 17: IGCC Performance model incorporating variable Carbon capture \& removal 32 iv $\underline{\text { Page }}$

7

8

10

10

12

13

17

25

26

26

27

30

30

31 
Tables:

$\underline{\text { Page }}$

Table 1 - CURC/EPRI/DOE Consensus Roadmap for IGCC Plant Requirements 6

Table 2 - Syngas Compositions Comparison of published data and Simulation Model 14

Table 3 - Comparison of Plant Performance for Baseline Model and published data 14

Table 4 - Syngas Composition of Modified Baseline Case 15

Table 5 -Modified Baseline 207 FA +e IGCC Summary Performance 15

Table 6 - Major Streams Data of Modified Baseline IGCC 16

Table 7 - Conceptual Design Option Results for Base Case and Cases 1 - $4 \quad 18$

Table 8 - Conceptual Design Option Results for Cases 5 - 9

Table 9 - Conceptual Design Option Results for Cases 10 - 14

Table 10 - Conceptual Design Option Results for Cases 15- $18 \quad 20$

Table 11 - Gas Turbine Cycle Influence Coefficients on IGCC Performance 21

Table 12 - IGCC Summary Performance of Gas Turbine Cycle Design Cases 1 thru 623

Table 13 - IGCC Summary Performance of Gas Turbine Cycle Design Cases 7 thru $12 \quad 23$

Table 14 - IGCC Summary Performance of Gas Turbine Cycle Design Cases 13 thru 1824

Table 15 - Gas Turbine Fuel Composition for $85 \%$ and $88 \%$ Carbon removal 32

Table 16 - IGCC Summary Performance of Gas Turbine Cycle Design Cases with 85 and $88 \%$ Carbon removal 34 


\section{Introduction}

\section{Systems Study for Improving GT Performance for Coal/IGCC Applications}

\section{A. Objective:}

This study identifies impact of gas turbine performance improvements on coal Integrated Gasification Combined Cycle (IGCC) plants and quantifies influence of vital gas turbine parameters in meeting the DOE Turbine Program overall IGCC plant goals of 50\% net HHV efficiency, $\$ 1000 / \mathrm{kW}$ capital cost, and low emissions. Focus is on air-cooled gas turbines for near-term, year 2008 operation in coal fed oxygen blown IGCC power plants with commercially demonstrated gasification, gas cleaning, \& air separation technologies. Gas Turbine conceptual design recommendation plan towards achieving DOE's goals for the Turbine Program is defined, and provides a total systems-level perspective to identify the development needs and improvements that have the highest impact/ payback to the program.

\section{B. Background/Relevancy}

Background:

In the near term as reliance on natural gas increases and prices escalate opportunities will arise to reinvest in the use of coal, our nations most abundant fossil fuel resource. Estimates suggest that more than 30 Gigawatts of new coal-based power generation will be installed over the next 15 years. The US generates approximately $50 \%$ of its power from coal. Much of this added capacity could be based on integrated gasification combined-cycle technology (IGCC). Significant improvements in overall cycle efficiency and cost per unit of power will dramatically reduce generation costs and emissions. This will help provide low-cost, environmentally acceptable power from a domestically abundant low cost fuel.

\section{Relevancy:}

Clean, efficient and cost effective coal based power systems depend on advanced power turbine technology to achieve higher levels of efficiency. IGCC technology has been demonstrated to show superiority in both performance and emissions compared with conventional coal power generation technology. However, additional enhancements in IGCC will be needed to gain superiority in life cycle electricity costs. One area of improvement is in the gas turbine portion of the cycle, which is the primary energy conversion device within an IGCC power plant. Increases in gas turbine conversion efficiency of coal derived syngas energy to power and higher utilization of exhaust energy will help drive lower IGCC plant level generating costs.

Meeting of DOE overall IGCC plant goals of 50\% net HHV efficiency, $\$ 1000 / \mathrm{kW}$ capital cost, and low emissions for a $500 \mathrm{MW}$ coal plant could provide annual generating cost savings of about $\$ 50 \mathrm{MM} / \mathrm{yr}$ compared to current F-Class IGCC systems and about $\$ 20$ $\mathrm{MM} / \mathrm{yr}$ compared to conventional PC technology. Additional enhancements in the area of emitted NOx and SOx could also be realized by making IGCC the technology of choice for coal based power production. Future IGCC plant could also be designed limiting atmospheric emissions of Carbon dioxide by using conventional Carbon removal technology. 


\section{Executive Summary}

Overall DOE Turbine Program plant level goals were established from DOE Vision 21 and IGCC Power Plant CURC Roadmap Studies. Using GE's Six Sigma Methodology, key gas turbine (GT) plant level requirements were identified. These gas turbine plant level requirements were used to quantify and prioritize gas turbine cycle parameters. A Baseline Conceptual IGCC System Design was established utilizing current General Electric (GE) F-class gas turbine technology based on a Midwest US IGCC site. An overall IGCC System Performance Model was constructed utilizing GE in- house proprietary software for the gas turbine \& steam turbine, and commercially available software for the balance of the systems. The model was exercised through parametric analysis to quantify gas turbine performance impact at IGCC plant system level. Various advanced $\mathrm{F}$ class technology gas turbine cycle design options were evaluated to determine performance impact on IGCC efficiency, cost and emissions. Results were used to identify gas turbine technology improvements for development consideration in future Turbine Program phases. The program includes the following six major tasks:

\section{Task 1 - Overall IGCC Plant Level Requirements Identification:}

This task established ranking of DOE's overall IGCC plant level goals of achieving $50 \%$ net HHV efficiency and $\$ 1000 / \mathrm{kW}$ in year 2008, and is used to prioritize plant level requirements. Using Six Sigma QFD tools, the key IGCC Plant Level parameters identified were: IGCC Net Efficiency, IGCC Net Output, GT Output and NOx Emissions. A subsequent QFD flow down identified the most significant GT Plant Level requirements as: Availability, Product Cost, Efficiency, Air Integration flexibility, syngas \& diluent supply conditions and syngas $\mathrm{NO}_{\mathrm{x}}$ Capability.

\section{Task 2 - Requirements Prioritization \& Flow-Down to Gas Turbine Subsystem Level}

This task prioritizes GT cycle design parameters from an IGCC Plant Level flow down to the GT subsystem level. The most significant GT cycle design parameters were identified as Firing Temperature, Combustor Options, Turbine and Compressor Efficiency, Compressor Pressure Ratio, Cooling Flows, Air Extraction amount, Syngas Supply and Diluent Supply Temperatures, Compressor Air Flow and Diluent Flow.

\section{Task 3 - IGCC Conceptual System Analysis}

A coal-based Baseline IGCC Configuration with Oxygen Blown Gasification and GE F-Class GT technology was defined and then used to validate a Baseline Case IGCC System Performance Simulation Analysis Model. The Simulation Analysis Model was reconfigured as a typical advanced IGCC powerplant by eliminating cogeneration of steam, adding heat recovery from GT air extraction, and using a GE steam turbine.

Using this revised IGCC System Performance Simulation Analysis model, eighteen new advanced F technology GT cycle options were analyzed to explore varying turbine configuration impacts that would provide performance targets with increased output and/or efficiency and low NOx emissions. These GT cycle design options were developed by varying the selected system parameters such as Air Integration Method, 
ASU type, Diluent Method, and Fuel Temperature, as well as GT parameters such as Combustor Type, available Hot Gas Path Configuration including future hardware components, Firing Temperature and Target NOx Level.

\section{Task 4 - Gas Turbine Cycle Options vs. Requirements Evaluation}

In this task, IGCC performance derivatives in terms of IGCC Net Plant Efficiency, IGCC Net Plant Output, GT Output and NOx Emissions were evaluated for 11 key GT cycle parameters. The following GT parameters were found to have the greatest impact on each respective plant level derivative: GT Firing Temperature, Turbine \& Compressor Efficiency, Diluent Supply Temperature, Compressor Pressure Ratio and Cooling Flows on IGCC Net Efficiency; Firing Temperature, Compressor Inlet Air Flow, Turbine \& Compressor Efficiency, Compressor Pressure Ratio and Dilution Flow on IGCC Net Output; Firing Temperature, Compressor Inlet Air Flow, Turbine \& Compressor Efficiency and Dilution Flow on GT Output; and Combustion Technology (Diffusion or Premix), Diluent Flow, Firing Temperature and Compressor Pressure Ratio on NOx Emissions.

Using these plant level derivative effects, GT cycle design trade-off studies utilizing the IGCC System Performance Simulation Model and Eighteen new gas turbine cycle options based on advanced F GT technology were analyzed. Results indicate that IGCC efficiency gains up to 2.8 pts (from $40.5 \%$ to $43.3 \%$ ) and IGCC net output gains up to $35 \%$ are possible while still maintaining single digit NOx emission levels with improvements in gas turbine technology alone.

\section{Task 5 - Recommendations for Gas Turbine Technical Improvements}

Various GT cycle designs results were examined to select the most promising candidate cycle concepts. The 3 most promising GT candidates are recommended on the basis of their merit on IGCC Efficiency, IGCC Net Output, GT Specific Output and NOx Emissions. For near term (2006): the recommended GT cycle design should have a $2400 \mathrm{~F}$ class firing temperature, base class compressor pressure ratio (CPR), diffusion combustor and integrated air extraction; for midterm (2008): a 2500F class firing temperature, base class CPR, diffusion combustor, and integrated air extraction; and for long term (2010): a 2600F class firing temperature, increased CPR, and further combustion and hot gas path technology enhancements. A turbine technology development roadmap is recommended for future coal based IGCC power plants.

\section{Task 6 - Determine Carbon Capture Impact on IGCC Plant Level Performance}

Performance impact of Coal fired IGCC plants using high Hydrogen fueled current and advanced technology gas turbine was analyzed due to Carbon capture and removal. A high Hydrogen fueled gas turbine performance model was created and integrated to an overall IGCC system performance model, which also included newly created subsystem models for moisturized syngas, gas shift and $\mathrm{CO} 2$ removal. Two gas turbine technology based IGCC systems were analyzed, each with two Carbon removal design options of $85 \%$ and $88 \%$ respectively. The results show larger IGCC performance penalty for gas turbine designs with higher firing temperature and higher Carbon removal. 


\section{Experimental}

Overview: Both commercially available software and GE in-house proprietary software packages were utilized in the analysis phases of this study. A brief description of their functionality is provided below.

\section{Task 1 - Overall IGCC Plant Level Requirements Identification:}

Plant level IGCC requirements were identified, and compared with DOE's IGCC Goals of achieving 50\% Net HHV Efficiency and $\$ 1000 / \mathrm{KW}$ by the Year 2008, through use of a Six Sigma Quality Functional Deployment (QFD) Tool. This GE in-house, Excel-based, proprietary tool provides a ranking of the importance of IGCC requirements relative to DOE's IGCC Goals.

\section{Task 2 - Requirements Prioritization \& Flow-Down to Gas Turbine Subsystem Level}

Gas turbine cycle design requirements were identified, analyzed and prioritized relative to achieving plant level goals, and compared with the flow down of power island goals through use of a Six Sigma Quality Functional Deployment (QFD) Tool. This GE in-house, Excel-based, proprietary tool provides a ranking of the importance of gas turbine requirements relative to power island goals.

\section{Task 3 - IGCC Conceptual System Analysis}

Overall integrated IGCC system performance model was constructed utilizing GE in-house proprietary software, GateCycle ${ }^{\mathrm{TM}}$ for the gas turbine \& steam turbine, and commercially available HYSYS Process Modeling software for the balance of the systems. The model is exercised by a parametric analysis in commercial ModelCenter software to quantify gas turbine performance impact at the IGCC plant system level.

\section{Task 4 - Gas Turbine Cycle Options vs. Requirements Evaluation}

This integrated IGCC system analysis model is used to determine the influence coefficients of vital Gas Turbine parameters (firing temperature, turbine and compressor efficiency, compressor pressure ratio, diluent and fuel temperature, etc.) on plant-level goals (efficiency, output, emissions, etc). This model is also used for IGCC performance evaluation of various advanced $\mathrm{F}$ technology gas turbine cycle design options.

\section{Task 5 - Recommendations for Gas Turbine Technical Improvements}

This task did not utilize software tools over and above those used in previous tasks.

\section{Task 6 - Determine Carbon Capture Impact on IGCC Plant Level Performance.}

The HYSYS model of the Low Temperature Gas Cooling (LTGC) System was modified to include two Water Saturators and two Water Gas Shift Reactors in order to provide the required shift of Syngas $\mathrm{CO}$ to $\mathrm{CO}_{2}$ necessary for the targeted $\mathrm{CO}_{2}$ removal from the Syngas. All MP and 
LP Steam within the LTGC System was diverted as a source of energy for the Saturators such that only Net HP Steam is now sent from the LTGC to the HRSG for all of the Carbon Capture cases.

A modified Acid Gas Removal (AGR) System was developed in order to simulate the removal of $\mathrm{CO}_{2}$ at the $90 \%$ and $95 \%$ level from the untreated Syngas. This AGR model was based on a traditional two-column Selexol System, with the addition of a $\mathrm{CO}_{2}$ Removal Section consisting of an additional Low-Temperature Absorption Column, three Flash Drums for $\mathrm{CO}_{2}$ separation, and refrigeration necessary for the low-temperature $\mathrm{CO}_{2}$ absorption process. 


\section{Results and Discussion}

\section{Task 1 - Results/Discussion:}

Overview: Gas turbine System level (Power Island) requirements were identified, and compared with DOE's IGCC Goal of achieving 50\% Net HHV Efficiency and $\$ 1000 / \mathrm{KW}$ by the Year 2008, through use of a Six Sigma Quality Functional Deployment (QFD) Tool.

\section{Task 1 Discussion:}

IGCC Plant Requirements for this study have been based on the DOE Vision 21 Performance Goal for 2008 which outlines a coal-based power system with:

1) System HHV based Efficiency of $50 \%$

2) Capital Cost of less than $\$ 1000 . / \mathrm{KW}$

3) $\mathrm{NO}_{\mathrm{x}}$ Reduction to less than $2 \mathrm{ppm}$

4) Increase of Heat Engine Efficiency of 2 to 3\%

5) Attainment of reliability/availability standards for pre-1999 gas turbines

These Plant Requirements are consistent with the CURC/EPRI/DOE Consensus Roadmap as shown below in table 1:

Table 1 - CURC/EPRI/DOE Consensus Roadmap for IGCC Plant Requirements

\begin{tabular}{|l|c|c|c|}
\hline \multicolumn{1}{|c|}{ Item } & Reference Plant & $\mathbf{2 0 1 0}$ & $\mathbf{2 0 2 0}$ \\
\hline Plant Efficiency $(\mathrm{HHV})$ & $40 \%$ & $45-50 \%$ & $50-60 \%$ \\
\hline Availability & $>80 \%$ & $>85 \%$ & $>90 \%$ \\
\hline Plant Capital Cost $(\$ / \mathrm{KW})$ & $1000-1300$ & $900-1000$ & $800-900$ \\
\hline Cost of Electricity (cents/KWh) & 3.5 & $3.0-3.2$ & $<3.0$ \\
\hline \multirow{3}{*}{ Air Emissions } & $98 \% \mathrm{SO}_{2}$ Removal & $99 \% \mathrm{SO}_{2}$ Removal & $>99 \% \mathrm{SO}_{2} \mathrm{Removal}^{6}$ \\
\cline { 2 - 4 } & $0.15 \mathrm{lb} / 10^{6} \mathrm{Btu} \mathrm{NO}_{\mathrm{x}}$ & $0.05 \mathrm{lb} / 10^{6} \mathrm{Btu} \mathrm{NO}_{\mathrm{x}}$ & $<0.01 \mathrm{lb} / 10^{6} \mathrm{Btu} \mathrm{NO}_{\mathrm{x}}$ \\
\cline { 2 - 4 } & $0.01 \mathrm{lb} / 10^{6}$ Btu Pariculate & $0.005 \mathrm{lb} / 10^{6} \mathrm{Btu}$ Pariculate & $0.002 \mathrm{lb} / 10^{6} \mathrm{Btu}$ Pariculate \\
\cline { 2 - 4 } & Mercury Removal & $90 \%$ & $95 \%$ \\
\hline By-Product Utilization & $30 \%$ & $50 \%$ & $\mathrm{Near} 100 \%$ \\
\hline
\end{tabular}

An analysis of DOE and customer requirements and expectations result in the following set of Power Plant Level Expectations (with corresponding levels of Importance, 5 being the highest):

\section{Power Plant Level Expectations, (Y's )}

Low Capital Cost $(<\$ 1000 / \mathrm{KW})$

High Net Electrical Efficiency (50\% HHV)

High Availability

Low COE

Low Emissions for $\mathrm{NO}_{\mathrm{x}}$ and $\mathrm{SO}_{\mathrm{x}}$

Fuel Flexibility

Co-Production Capable

$\mathrm{CO}_{2}$ Removal

Reduced $\mathrm{H}_{2} \mathrm{O}$ Use

Zero Process Discharge

\begin{tabular}{c} 
Importance \\
\hline 5 \\
5 \\
5 \\
3 \\
3 \\
3 \\
3 \\
3 \\
2 \\
2
\end{tabular}

\section{Notes:}

$\$ 900-1000 / \mathrm{KW}$ by 2010

Not Co-Gen or $\mathrm{CO}_{2}$ Capture Value $85 \%$ by 2010 through RAM Excellence 3.2 cents/KWH by 2010

2 PPM NOx, 99\% Sulfur Removal Low to High Rank Coals, Petcoke Chemical Co-Production, Hydrogen $85 \% \mathrm{CO}_{2}$ Removal

Driven by Permitting Requirements Driven by Permitting Requirements 
A corresponding set of Gas Turbine Power Island Level Requirements were established as input to the Quality Functional Deployment analysis:

Gas Turbine Power Island Requirements, (X's)

Product Cost $(\$ / \mathrm{KW})$

Generator Output

Efficiency

Availability

Syngas $\mathrm{NO}_{\mathrm{x}}$

Syngas CO

Syngas Fuel Flexibility

Syngas and Diluent Supply Conditions

Diluent Flexibility

Exhaust Gas Energy

Air Integration Flexibility
Notes:

Target of $\$ 200 / \mathrm{KW}$

Maximize

Drives Overall IGCC Efficiency

At Least $95 \%$

9 ppm Ceiling by 2010

9 ppm Ceiling by 2010

Variable CO, H2 Composition

Efficiency, Combustor Requirements

For $\mathrm{NO}_{\mathrm{x}}$ Removal

Effect Bottoming Cycle Efficiency

With Air Separation Unit

These Expectations and Plant Requirements are mapped in Figure 1 through the QFD tool, with the weighting factors for the expectations, and the Y's are analyzed against the X's through Low (L), Medium (M) and High (H) levels of connection, with the following results matrix:

\section{IGCC Systems Study QFD}

\begin{tabular}{|c|c|c|c|c|c|c|c|c|c|c|c|c|c|}
\hline Expectation & 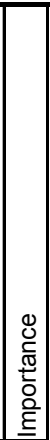 & 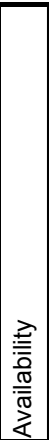 & 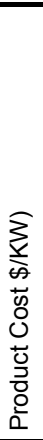 & 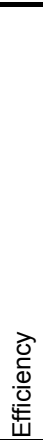 & 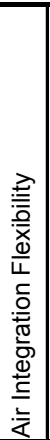 & 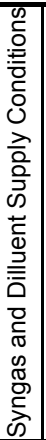 & 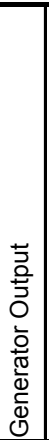 & 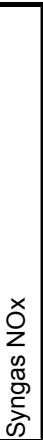 & 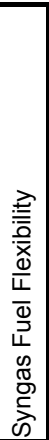 & 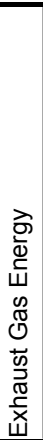 & 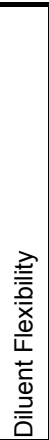 & 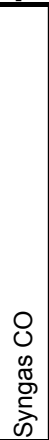 & 要 \\
\hline High Availability & 5 & $\mathrm{H}$ & $\bar{M}$ & & $\mathrm{M}$ & & & $\mathrm{L}$ & $M$ & & $L$ & & $\frac{100}{170}$ \\
\hline High Net Electrical Efficiency - 50\% HHV & 5 & & $\mathrm{~L}$ & $\mathrm{H}$ & $\mathrm{M}$ & $\mathrm{H}$ & M & $\mathrm{M}$ & & $\mathrm{M}$ & $\mathrm{M}$ & $\mathrm{L}$ & 175 \\
\hline Low Capital Cost $\$ 1000 / \mathrm{KW}$ & 5 & $\mathrm{M}$ & $\mathrm{H}$ & $\mathrm{L}$ & $\mathrm{M}$ & $\mathrm{M}$ & $\mathrm{H}$ & $\mathrm{L}$ & $\mathrm{L}$ & $\mathrm{M}$ & & & 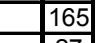 \\
\hline CO2 Removal & 3 & $\mathrm{~L}$ & & $\mathrm{~L}$ & $\mathrm{M}$ & & & $\mathrm{M}$ & & & $\mathrm{L}$ & & 27 \\
\hline Coproduction Capabl & 3 & $\mathrm{~L}$ & & & $\mathrm{M}$ & $\mathrm{M}$ & & & $\mathrm{M}$ & & $\mathrm{L}$ & & 33 \\
\hline 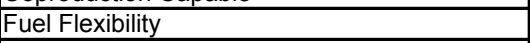 & 3 & & & & $\mathrm{M}$ & $\mathrm{L}$ & & & $\mathrm{M}$ & & $\mathrm{L}$ & & 24 \\
\hline Low COE & 3 & $\mathrm{H}$ & $\mathrm{H}$ & $\mathrm{M}$ & $\mathrm{M}$ & $\mathrm{M}$ & $\mathrm{M}$ & $\bar{L}$ & $\mathrm{~L}$ & $\mathrm{M}$ & $\mathrm{L}$ & & 108 \\
\hline Low Emissions Max $0.02 \mathrm{lb} / \mathrm{MMBTU}$ NOx and & 3 & & & $\mathrm{H}$ & $\mathrm{L}$ & $\mathrm{L}$ & $\mathrm{L}$ & $\bar{H}$ & $\bar{M}$ & $\mathrm{M}$ & $L$ & $\mathrm{M}$ & 93 \\
\hline Reduced $\mathrm{H} 2 \mathrm{O}$ Use & 2 & & & & $\mathrm{~L}$ & & & $\mathrm{M}$ & $\mathrm{L}$ & $L$ & $\mathrm{M}$ & & 18 \\
\hline Zero Process Discharge & 2 & & & & $\mathrm{~L}$ & & & & & & & & 2 \\
\hline Total & & 93 & 92 & 89 & 88 & 84 & 72 & 70 & 52 & 50 & 41 & 14 & \\
\hline
\end{tabular}

Figure 1 - Matrix for Plant Level QFD

An alternate representation of the results of the QFD process is the Pareto Chart in Figure 2: 


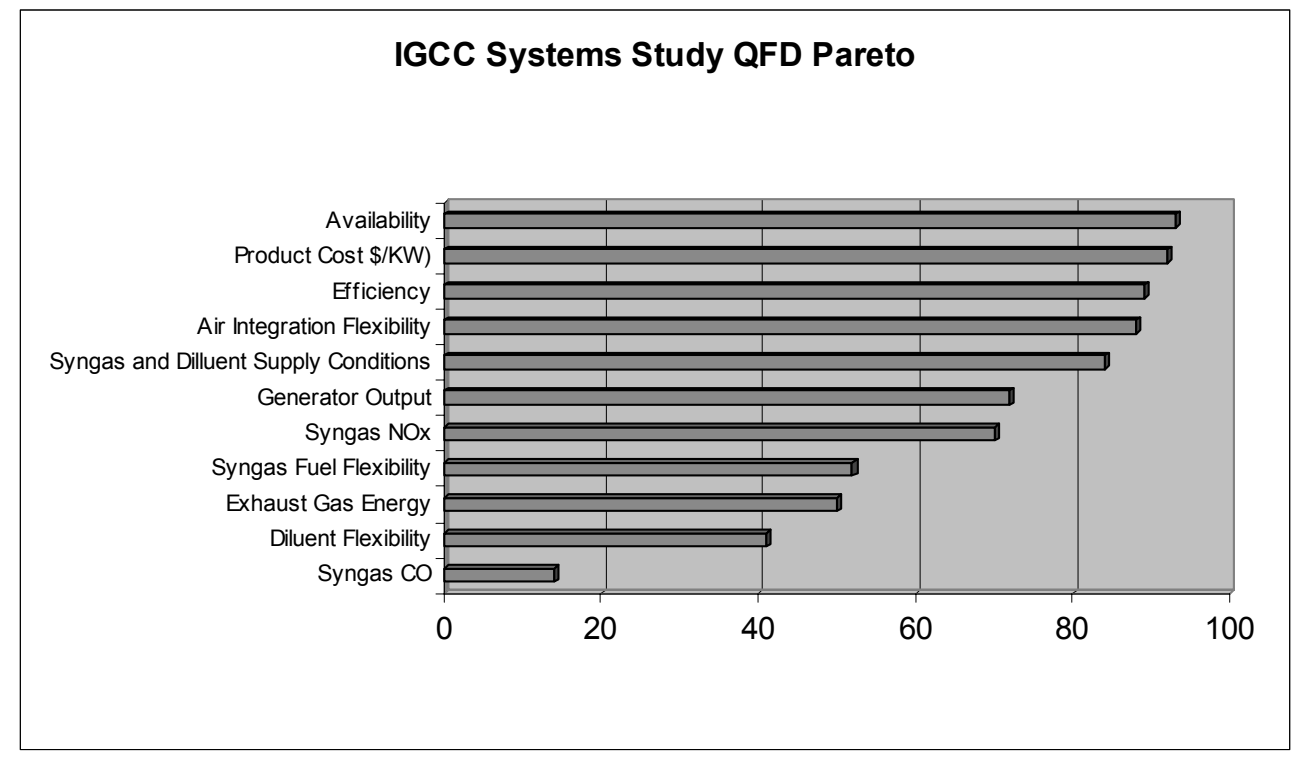

\section{Figure 2 - Pareto for Plant Level QFD}

The following 7 IGCC Gas Turbine System Level Parameters were selected as the most significant for further analysis of IGCC system requirements at the power island level:
1) Availability
2) Product Cost
3) Efficiency
4) Air Integration Flexibility
5) Syngas and Diluent Supply Conditions
6) Generator Output
7) Syngas $\mathrm{NO}_{\mathrm{x}}$ Capability

\section{Task 2 - Results/Discussion:}

Overview: Gas turbine cycle requirements were identified, analyzed and prioritized relative to achieving plant level goals, and compared with the flowdown of power island goals through use of a Six Sigma Quality Functional Deployment (QFD) Tool.

\section{Task 2 Discussion:}

The previous Plant Level Requirements are flowed down as part of the QFD process to yield the following set of Power Island Level Expectations (with corresponding levels of Importance): 


\section{Y's}

Gas Turbine Power Island Requirements

Availability

Gas Turbine Cost $(\$ / \mathrm{KW})$

Efficiency

Air Integration Flexibility

Syngas and Diluent Supply Conditions

Exhaust $\mathrm{NO}_{\mathrm{x}}$

Generator Output

Syngas Fuel Flexibility

Exhaust Gas Energy

Diluent Flexibility

Exhaust CO

\section{Importance}

5

5

5

5

5

4

4

3

3

3

2

A corresponding set of Gas Turbine Cycle Requirements were established as input to the Quality Functional Deployment analysis:

\section{X's}

Gas Turbine Cycle Design Options

Compressor Air Flow

Compressor Pressure Ratio

Firing Temperature

Combustor Pressure Drop

Cooling Flows

Syngas Supply Temperature

Syngas Supply Pressure

Diluent Supply Temperature

Diluent Supply Pressure

Diluent Flow

Diluent Type

Turbine \& Compressor Efficiency

Combustor Options

Percent Air Extraction

Exhaust Temperature

\section{Notes:}

Impacts size and cost

Impacts GT plant efficiency, output

Maximize for HGP materials

Minimize

Minimize

Maximize

Minimize

Maximize

Minimize

Optimize

Nitrogen, Steam, Pre-Moisturized

Optimize for syngas fuel

Diffusion, Premix Combustors

Air Extraction Range, Effects on Performance

Gas Turbine Exhaust Effects

These Gas Turbine Cycle Design options and Power Island Requirements are mapped through the Six Sigma QFD tool, with the weighting factors for the expectations, and the Y's are analyzed against the X's through Low, Medium and High levels of connection, with the following results matrix as shown in Figure 3: 


\begin{tabular}{|c|c|c|c|c|c|c|c|c|c|c|c|c|c|c|c|c|c|}
\hline Gas Turbine Power Island Requirements & 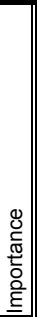 & 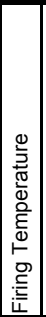 & 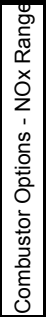 & 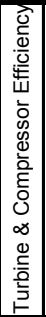 & 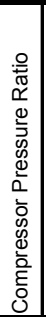 & $\begin{array}{c}0 \\
\vdots \\
0 \\
\frac{0}{4} \\
0 \\
. \bar{\Xi} \\
8 \\
0\end{array}$ & 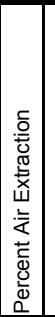 & 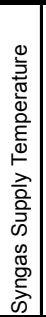 & 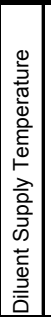 & 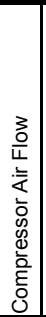 & 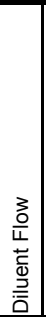 & 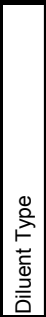 & 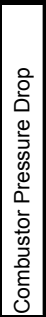 & 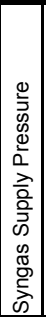 & 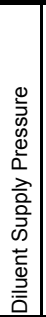 & 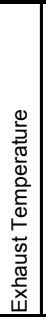 & $\begin{array}{l}\bar{\pi} \\
\stackrel{\square}{\circ} \\
\end{array}$ \\
\hline Air Integration Flexibility & 5 & $\mathrm{~L}$ & $\mathrm{M}$ & $\mathrm{M}$ & $\mathrm{H}$ & $\mathrm{L}$ & $\mathrm{H}$ & & $\mathrm{L}$ & $\mathrm{M}$ & & & $\mathrm{L}$ & & $\mathrm{L}$ & $\mathrm{L}$ & 165 \\
\hline Availability & 5 & $\mathrm{H}$ & $\mathrm{M}$ & & & $\mathrm{H}$ & $\mathrm{M}$ & & & & & & & & & & 120 \\
\hline Efficiency & 5 & $\mathrm{H}$ & $\mathrm{M}$ & $\mathrm{M}$ & $\mathrm{H}$ & $\mathrm{H}$ & $\mathrm{M}$ & $\mathrm{M}$ & $\mathrm{M}$ & $\mathrm{L}$ & $\mathrm{M}$ & $\mathrm{M}$ & $\mathrm{M}$ & & & $\mathrm{M}$ & 275 \\
\hline Gas Turbine Cost $\$ / \mathrm{KW})$ & 5 & $\mathrm{H}$ & $\mathrm{M}$ & $\mathrm{H}$ & $\mathrm{M}$ & $\mathrm{L}$ & $\mathrm{L}$ & $\mathrm{M}$ & $\mathrm{M}$ & $\mathrm{M}$ & $\mathrm{L}$ & $\mathrm{L}$ & $\mathrm{L}$ & $\mathrm{L}$ & $\mathrm{L}$ & $\mathrm{L}$ & 205 \\
\hline Syngas and Dilluent Supply Conditions & 5 & & $\mathrm{H}$ & $\mathrm{M}$ & $\mathrm{H}$ & & $\mathrm{M}$ & $\mathrm{H}$ & $\mathrm{H}$ & & $\mathrm{M}$ & $\mathrm{M}$ & $\mathrm{M}$ & $\mathrm{H}$ & $\mathrm{H}$ & & 345 \\
\hline Generator Output & 4 & $\overline{\mathrm{H}}$ & $\mathrm{M}$ & $\mathrm{H}$ & $\mathrm{L}$ & $\mathrm{M}$ & $\mathrm{M}$ & $\mathrm{L}$ & $\mathrm{L}$ & $\mathrm{H}$ & $\mathrm{M}$ & $\mathrm{M}$ & $\mathrm{L}$ & & & $\mathrm{M}$ & 196 \\
\hline Syngas NOx & 4 & $\mathrm{H}$ & $\mathrm{H}$ & $\mathrm{H}$ & $\mathrm{L}$ & $\mathrm{M}$ & $\mathrm{M}$ & $\mathrm{M}$ & $\mathrm{M}$ & & $\mathrm{M}$ & $\mathrm{L}$ & $\mathrm{M}$ & & & & 188 \\
\hline Diluent Flexibility & 3 & & $\mathrm{H}$ & $\mathrm{H}$ & & & $\mathrm{L}$ & & $\mathrm{L}$ & & $\mathrm{M}$ & $\mathrm{M}$ & $\mathrm{L}$ & & $\mathrm{L}$ & $\mathrm{M}$ & 93 \\
\hline Exhaust Gas Energy & 3 & $\mathrm{H}$ & $\mathrm{M}$ & $\mathrm{H}$ & $\mathrm{H}$ & $\mathrm{M}$ & $\mathrm{L}$ & & & $\mathrm{M}$ & $\mathrm{L}$ & $\mathrm{L}$ & & & & $\mathrm{M}$ & 126 \\
\hline Syngas Fuel Flexibility & 3 & $\mathrm{~L}$ & $\mathrm{H}$ & $\mathrm{M}$ & & & $\mathrm{L}$ & $\mathrm{M}$ & & & $\mathrm{L}$ & $\mathrm{L}$ & $\mathrm{L}$ & $\mathrm{M}$ & & & 69 \\
\hline Syngas $\mathrm{CO}$ & 2 & $\mathrm{M}$ & $\mathrm{H}$ & $\mathrm{M}$ & & $\mathrm{M}$ & $\mathrm{M}$ & $\mathrm{L}$ & $\mathrm{L}$ & & $\mathrm{L}$ & $L$ & $\mathrm{~L}$ & & & & 52 \\
\hline Total & & 248 & 234 & 231 & 185 & 139 & 134 & 102 & 101 & 80 & 76 & 68 & 64 & 59 & 58 & 55 & \\
\hline
\end{tabular}

\section{Figure 3 - Matrix for IGCC Gas Turbine QFD}

An alternate representation of the results of the QFD process is the Pareto Chart in Figure 4:

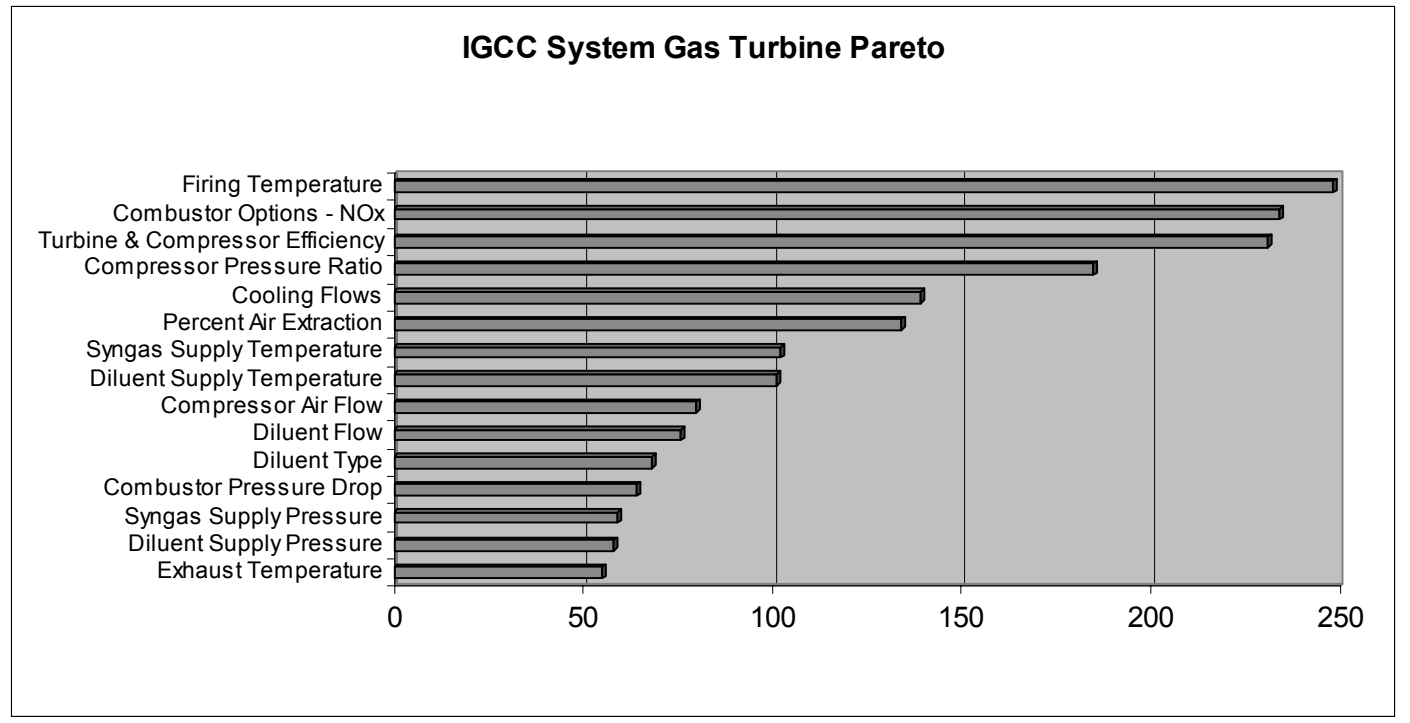

Figure 4 - Pareto for Gas Turbine QFD 
The following 11 IGCC Gas Turbine Parameters were selected as the most significant for analysis of Baseline and other IGCC system configurations:

1) Firing Temperature

2) Combustor Options

3) Turbine Efficiency

4) Compressor Efficiency

5) Compressor Pressure Ratio

6) Cooling Flows

7) Percent Air Extraction

8) Syngas Supply Temperature

9) Diluent Supply Temperature

10) Compressor Air Flow

11) Diluent Flow

\section{Task 3 - Results/Discussion:}

Overview: A Baseline IGCC Plant configuration and its performance design basis were chosen. An integrated simulation analysis model of IGCC was constructed to validate the Baseline IGCC Plant model against published performance data. The model was exercised by a parametric analysis to quantify the influence of key gas turbine parameters on performance impact at the IGCC plant system level. Various gas turbine cycle design options were chosen to evaluate performance effects on IGCC at plant level and select appropriate gas turbine technical improvements.

Task 3 Discussion:

\section{Task 3.1 - Establish IGCC System Design Basis}

During this task, a Baseline IGCC System was chosen as follows:

1) Determined the appropriate gasifier and F-Class Baseline IGCC Plant configuration.

2) Evaluated the Energy Flow "Sankey Diagram" for the Baseline IGCC Plant.

3) Evaluated overall heat and mass balances for Baseline IGCC Plant.

4) Developed an Integrated IGCC Simulation Analysis Model for the Baseline IGCC Plant configuration, and validated this model against published performance data.

The Reference Plant was chosen on the basis of a design which was representative of GE Frame 7FA+e current technology with sufficient public information to perform a detailed performance comparison with the results for that configuration by the Integrated IGCC Simulation Analysis Model. The chosen plant design was the Nordic Energy of Ashtabula (1) case with:

- ISO ambient conditions

- $\quad$ Pittsburgh No. 8 Coal

- $\quad$ E-Gas oxygen blown gasifier

- High pressure cryogenic Air Separation Unit 
- HP steam heat recovery similar to Ashtabula study

- COS hydrolysis, wet particulate removal

- Syngas saturation, heating and low temperature heat recovery

- Amine based acid gas cleanup and sulfur recovery

- $\quad 7 \mathrm{FA}+\mathrm{e}$ gas turbine with $2300{ }^{\circ} \mathrm{F}$ firing temperature

- $\quad$ Air extraction and $\mathrm{N}_{2}$ injection

- 3 pressure HRSG

- Reheat 1450 psig/1000F/1000F/ 1.5 in. steam turbine

- Cooling tower, transformer and plant auxiliaries included

The overall configuration of the Baseline Plant is given in Figure 5:

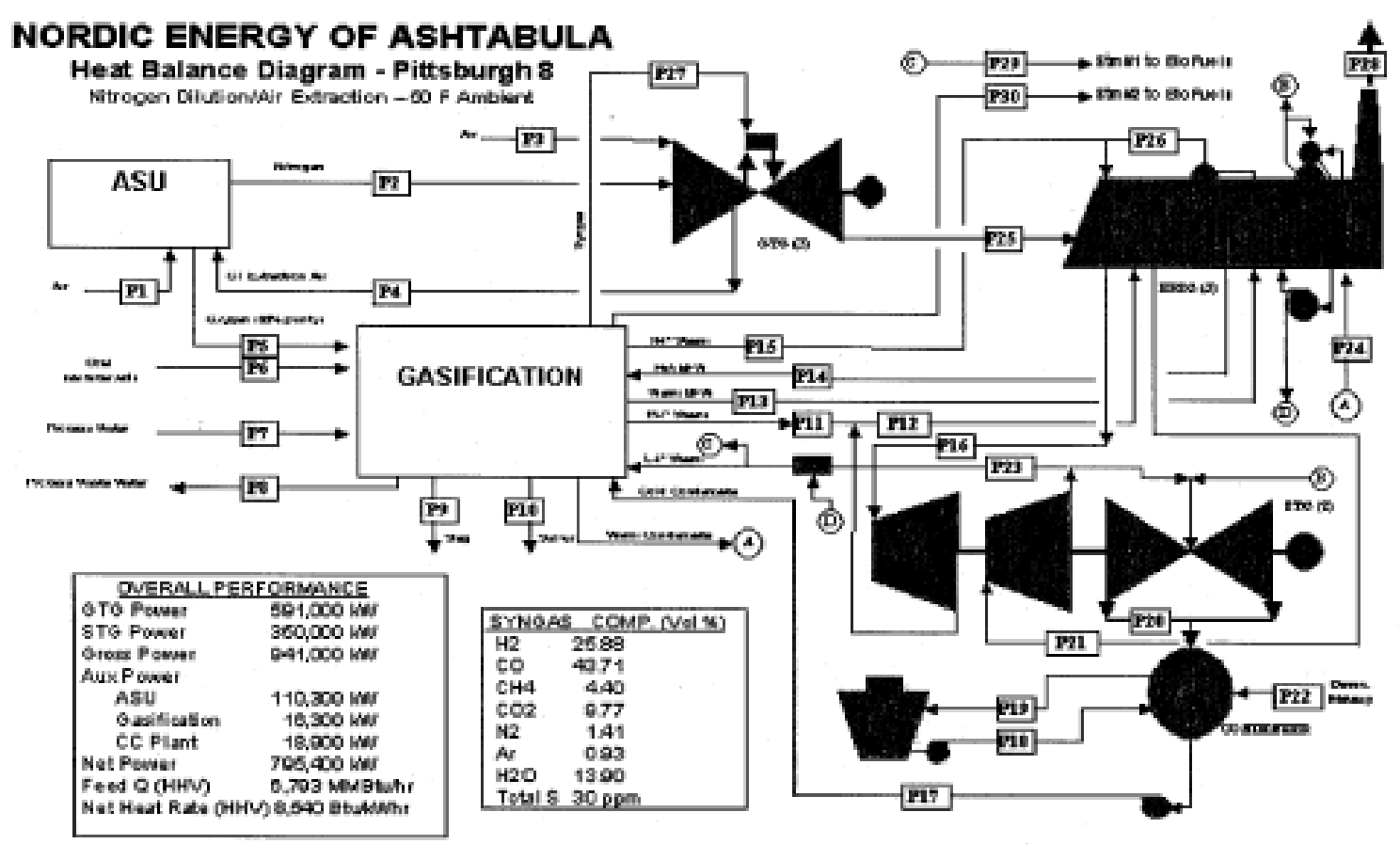

Figure 5 - Baseline IGCC Plant Configuration and Performance

\section{Task 3.2 - Develop System Models and Analyze IGCC System Performance}

An Integrated IGCC Simulation Analysis Model for the Baseline IGCC Plant configuration was developed with the following configuration and capabilities:

- E-Gas gasifier

- Air extraction integrated high pressure Air Separation Unit

- Gas turbine cycle for detailed performance evaluation

- 3 pressure, reheat steam cycle

- $\quad \mathrm{N}_{2}$ saturation and injection

- $\quad$ Syngas fuel saturation and heating

- Syngas heat recovery

- Sulfur removal and recovery 
This Simulation Analysis Model as shown in Figure 6 utilized in-house tools including a GateCycle ${ }^{\mathrm{TM}}$ model of a gas turbine suitable for syngas fuel application. This gas turbine model was integrated with a steam turbine, HRSG combined cycle model using GateCycle ${ }^{\mathrm{TM}}$ software. This combined cycle subsystem model was integrated, through use of ModelCenter commercial Software, with a performance simulation model of gasification, ASU, syngas cooling and AGR subsystems utilizing HYSIS commercial software.

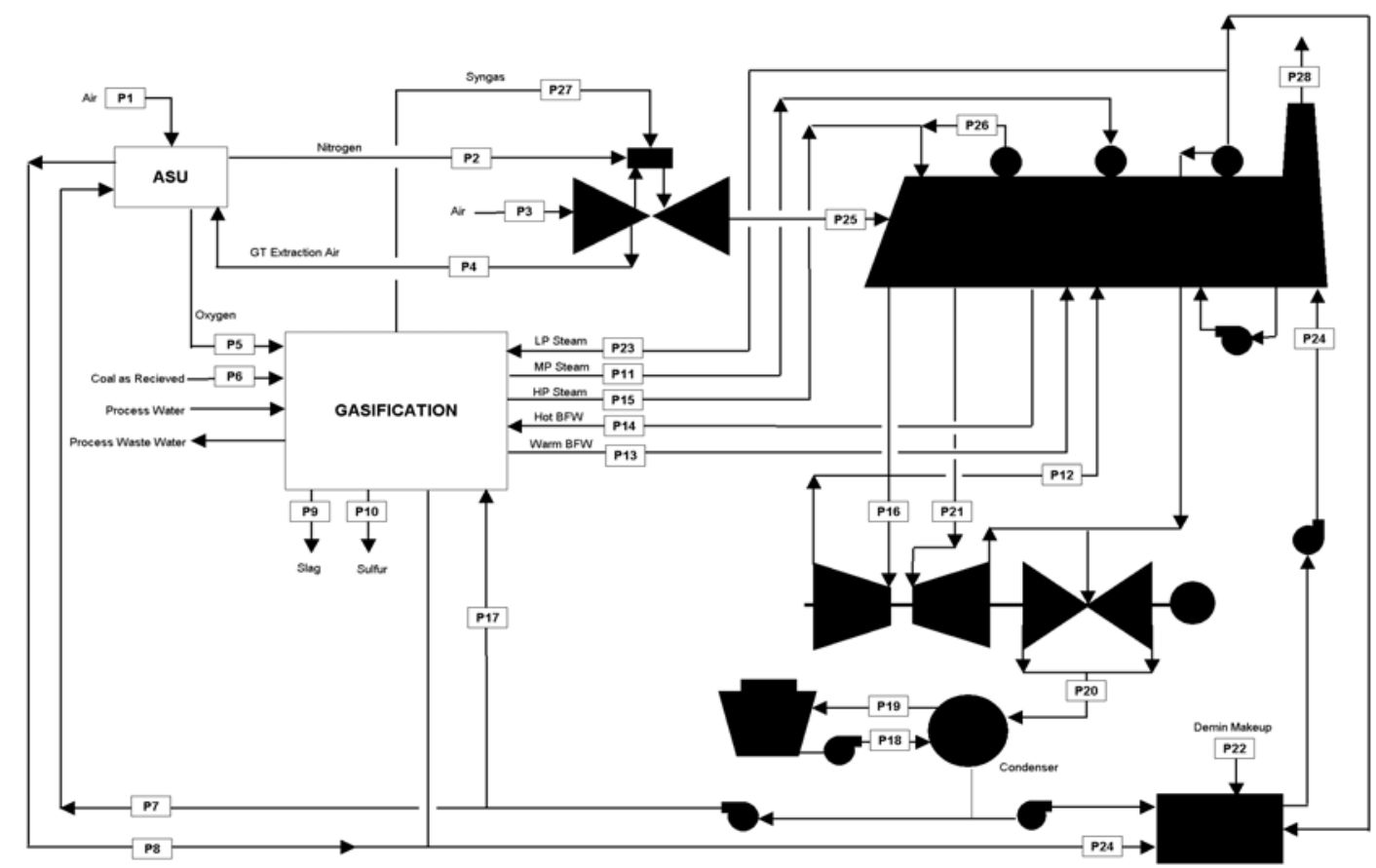

Figure 6 - Integrated IGCC Simulation Analysis Model of Baseline IGCC Plant

The Simulation Analysis Model of the Baseline Case yielded results in very good agreement with the published literature of Nordic Energy Ashtabula Plant. A comparison of syngas compositions for the model and simulation cases in Table 2 shows very good agreement (with Simulation results scaled up to be consistent with the 3x7FA+e Ashtabula and 2x7FA+e Baseline Case configurations). 
Table 2 -Syngas Composition Comparison of published data and Simulation Model

\section{Syngas Compositions (Mole Percent)}

$\begin{array}{lcr}\text { Species } & \text { Nordic Energy Ashtabula Case } & \text { Simulation } \\ \mathrm{H}_{2} & 25.88 & 25.99 \\ \mathrm{CO} & 43.71 & 43.94 \\ \mathrm{CH}_{4} & 4.40 & 4.42 \\ \mathrm{CO}_{2} & 9.77 & 9.67 \\ \mathrm{~N}_{2} & 1.41 & 1.09 \\ \mathrm{Ar} & 0.93 & 1.06 \\ \mathrm{H}_{2} \mathrm{O} & 13.90 & 13.83\end{array}$

A comparison of performance data for the Ashtabula and Simulation case in Table 3 also showed very good agreement. We note that the Baseline Case simulation exhibits an appreciably better heat rate since the Baseline Case simulation does not contain the modest co-generation steam included in the Ashtabula case)

Table 3 - Comparison of Plant Performance for Model and Simulation Cases

\section{$\underline{\text { IGCC Plant Performance }}$}

$\underline{\text { Parameter }}$

Gas Turbine Output (MW)

Steam Turbine Output (MW)

Auxiliary Power (MW)

Net Power Output (MW)

Net Heat Rate (HHV) (Btu/Kw-hr) $\underline{\text { Nordic Energy Ashtabula Case }}$

591.0

350.0

$-145.5$

795.4

8540.

\section{$\underline{\text { Simulation Case }}$}

590.7

343.5

$-141.5$

792.7

8464.

The Baseline IGCC configuration was further modified to model a 207FA+e based IGCC plant and incorporated the following additional changes:

1) Air extraction heat recovery

2) GE steam turbine with suitable LP last stage

The syngas composition, summary performance and streams data for the Modified Baseline

Case are presented in Tables 4, 5 and 6 respectively. 
Table 4 - Syngas Composition for Modified Baseline Case

\begin{tabular}{|cr|}
\hline Syngas Comp & \multicolumn{1}{c|}{ Vol \% } \\
\hline $\mathrm{H} 2$ & $25.97 \%$ \\
$\mathrm{CO}$ & $43.89 \%$ \\
$\mathrm{CH} 4$ & $4.42 \%$ \\
$\mathrm{CO} 2$ & $9.66 \%$ \\
$\mathrm{~N} 2$ & $1.09 \%$ \\
$\mathrm{Ar}$ & $1.06 \%$ \\
$\mathrm{H} 2 \mathrm{O}$ & $13.90 \%$ \\
Total S & $31.2 \mathrm{ppm}$ \\
\hline
\end{tabular}

Table 5: Modified Baseline 207 FA +e IGCC Summary Performance

\begin{tabular}{|lrl|}
\hline Overall Performance & & Units \\
\hline GT Power & 393200 & $\mathrm{~kW}$ \\
ST Power & 227600 & $\mathrm{~kW}$ \\
Aux Power & & \\
$\quad$ ASU & 71800 & $\mathrm{~kW}$ \\
$\quad$ Gasification & 11400 & $\mathrm{~kW}$ \\
$\quad$ CC Plant & 11100 & $\mathrm{~kW}$ \\
Net Power & 526500 & $\mathrm{~kW}$ \\
Feed Q (HHV) & 4429 & $\mathrm{MMbtu} / \mathrm{hr}$ \\
Net Heat Rate (HHV) & 8413 & Btu/kW-hr \\
Net Efficiency (HHV) & $40.59 \%$ & \\
Net Heat Rate (LHV) & 8126 & Btu/kW-hr \\
Net Efficiency (LHV) & $42.03 \%$ & \\
\hline
\end{tabular}


Table 6: Major Streams Data of Modified Baseline IGCC

\begin{tabular}{|c|c|c|c|c|}
\hline Stream & Description & Flow (lb/hr) & Pressure (psia) & Temperature $(\mathbf{F})$ \\
\hline P1 & Air to ASU & 812700 & 14.7 & 59 \\
\hline P2 & Nitrogen to GT & 961700 & 340 & 533 \\
\hline P3 & Air to GT & 6667600 & 14.7 & 59 \\
\hline P4 & Air Extraction from GT & 466700 & 234 & 771 \\
\hline P5 & O2 to Gasification & 289100 & 624 & 240 \\
\hline P6 & Coal (as received) & 334000 & & \\
\hline P7 & Cond to ASU & 372100 & 35 & 88 \\
\hline P8 & Cond Return from ASU & 372100 & 32 & 221 \\
\hline P9 & Slag & 52400 & & \\
\hline P10 & Sulfur & 7100 & & \\
\hline P11 & MP steam from Gasification & 16200 & 423 & 455 \\
\hline P12 & Cold Reheat Steam & 1076900 & 394 & 654 \\
\hline P13 & MP BFW & 16200 & 426 & 407 \\
\hline P14 & Hot BFW & 609500 & 1746 & 561 \\
\hline P15 & HP Steam & 609500 & 1746 & 617 \\
\hline P16 & Superheated HP Steam & 1099500 & 1682 & 1034 \\
\hline P17 & Cold Condensate & 1006700 & 80 & 88 \\
\hline P18 & Cond CW Supply & 84824800 & & 71 \\
\hline P19 & Cond CW Return & 84824800 & & 86 \\
\hline P20 & Steam Turbine Exhaust & 1270800 & 0.7367 & 92 \\
\hline P21 & Hot Reheat Steam & 1301100 & 371 & 1034 \\
\hline P22 & Demin Makeup & 220000 & 15 & 59 \\
\hline P23 & LP steam Extraction & 75900 & 70 & 607 \\
\hline P24 & Warm Condensate & 876200 & 159 & 174 \\
\hline P25 & GT Exhaust & 7934100 & 17 & 1079 \\
\hline P26 & HRSG HP Steam & 490000 & 1731 & 616 \\
\hline P27 & Syngas & 745500 & 375 & 533 \\
\hline P28 & HRSG Stack & 7934100 & 15 & 268 \\
\hline P29 & Steam Injection to GT & 0 & 388 & 653 \\
\hline
\end{tabular}




\section{Task 3.3 - Develop Gas Turbine Conceptual Design Options}

Gas turbine cycle design options illustrated in Figure 7 were developed by varying the selected system parameters such as Air Integration Method, ASU type, Diluent Method, and Fuel Temperature, as well as gas turbine parameters such as Combustor Type, Hot Gas Path Configuration, Firing Temperature and Target $\mathrm{NO}_{\mathrm{x}}$ Level.

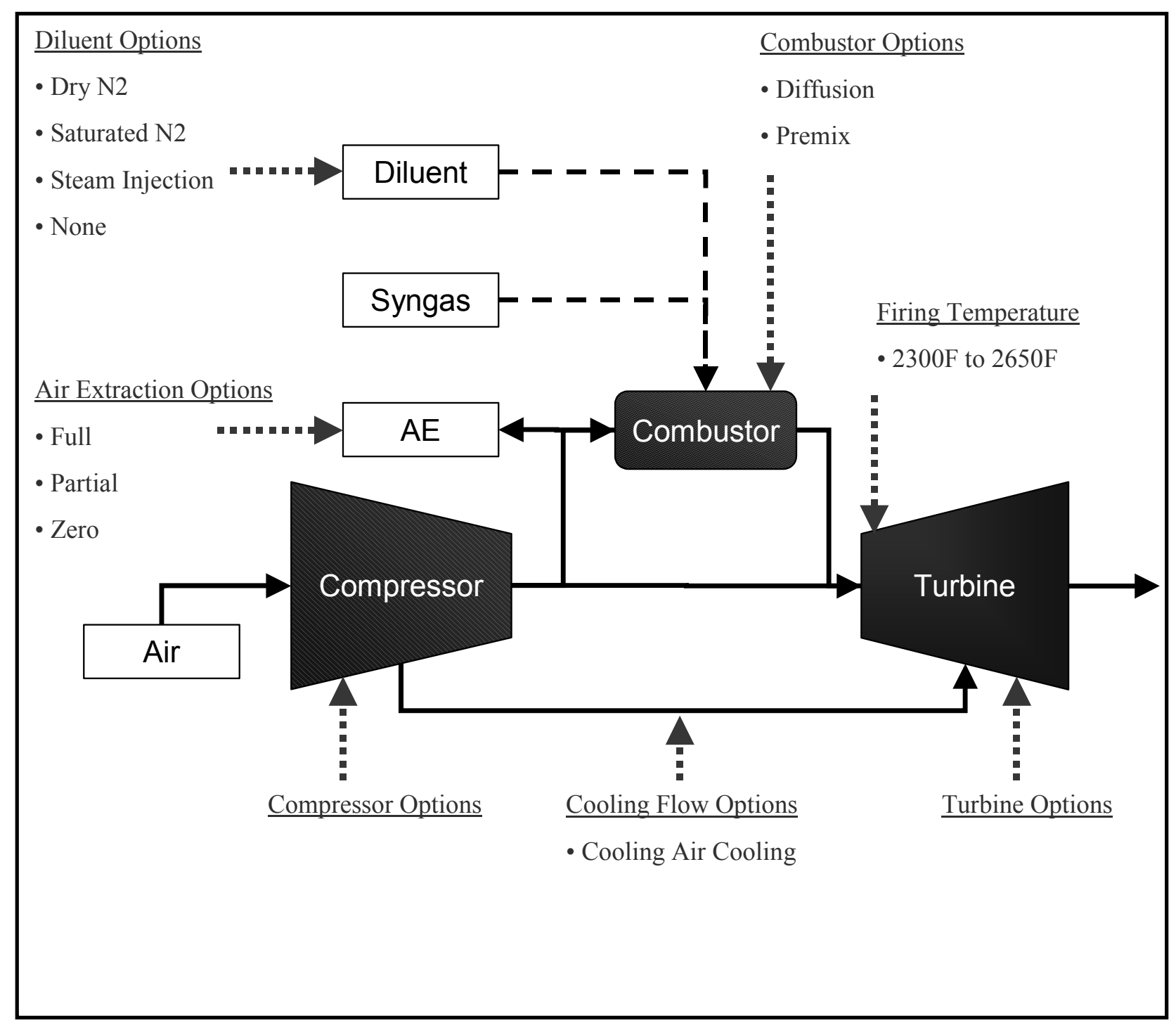

\section{Figure 7 - Gas Turbine Configuration Options}

IGCC subsystem models developed in the previous task were exercised to create performance results for these cycle configurations in the integrated IGCC environment. These configuration performance results enable the determination of the performance effects of gas turbine technical improvements on IGCC plant-level performance. 
Configuration details for the Base Case and 18 chosen Conceptual Design Options are presented in the following Tables 7 through 10:

Table 7 - Conceptual Design Option Results for Base Case and Cases 1 - 4.

\begin{tabular}{|lcccccc|}
\hline \multicolumn{7}{c|}{ Gas Turbine and Systems Configurations } \\
\hline Parameters & Base & Case 01 & Case 02 & Case 03 & Case 04 \\
\hline ASU Type & EP & EP & EP & EP & LP \\
Air Integration & Partial & Partial & Partial & Full & None \\
Diluent Type & N2 + Fuel Sat & N2 Sat + Fuel & N2 Sat + Fuel & N2 Sat + Fuel & Steam Inj + \\
Fuel Temperature & 533 & Sat & Sat & Sat & Fuel Sat \\
Compressor & FA+e & FB & 533 & 533 & 533 \\
Combustor Type & Diffusion & Diffusion & Diffusion & Diffusion & Diffusion \\
Cooling Air Cooling & No & No & No & No & No \\
SCR & None & None & Yes & Yes & Yes \\
Firing Temperature (F) & 2300 & 2400 & 2500 & 2500 & 2500 \\
NOx (ppmvd @ 15\%O2) & 15 & 15 & 9 & 9 & 9 \\
\hline
\end{tabular}

These Conceptual Design Options were set up to cover the gamut of turbine options within the available, as well as future, hardware components. First three cases use diffusion combustion, FB compressor and variation of turbine hot gas path geometry. Case 1 does not use SCR and limits NOx emissions to current EPA emission standards at 15 ppmvd @15\% corrected O2. Case 2 and 3 use SCR to get single digit NOx. Cases 4 and 5 use no air integration, standard low pressure cryogenic ASU, fuel saturation, current Natural gas fueled FB gas turbine Hot Gas Path and scaled down FB compressor. Case 4 uses Diffusion combustor and SCR, while Case 5 uses Premix combustor to limit NOx to 15 ppmvd@15\% corrected O2.

Cases 6 through 9 use Elevated Pressure ASU, Premix combustor, standard FB compressor and variation of turbine hot gas path geometry. Cases 6 and 7 use enough diluents as not to require SCR, while Case 8 requires SCR to limit NOx to single digit level. Cases 9 through 11 use $\mathrm{FA}+\mathrm{e}$ compressor and turbine hot gas path geometry and no SCR to limit NOx to 15 ppmvd@15\% corrected O2. Case 9 and 10 use Diffusion combustor, EP ASU and N2 and fuel saturation as diluents. Case 11 uses LP ASU and saturated fuel in a premix combustor. Cases 12 through 16 use new compressor and turbine geometry, premix combustor and higher fuel and diluent temperatures to increase thermal efficiency. Cases 12 through 14, use nitrogen and fuel saturation but no SCR, while Cases 15 and 16 use SCR to limit NOx to single digits. 
Table 8 - Conceptual Design Option Results for Cases 5 - 9

\begin{tabular}{|lcccccc}
\hline \multicolumn{7}{c}{ Gas Turbine and Systems Configurations } \\
\hline Parameters & Case 05 & Case 06 & Case 07 & Case 08 & Case 09 \\
\hline ASU Type & LP & EP & EP & EP & EP \\
Air Integration & None & Partial & None & Full & Full \\
Diluent Type & Fuel Sat & N2 Sat + Fuel & N2 Inj + Fuel & N2 Inj & N2 Sat + Fuel \\
Fuel Temperature & 533 & 533 & Sat & Sat \\
Compressor & Reduced FB & FB & FB & FB & FA+e \\
Combustor Type & DLN & DLN & DLN & DLN & Diffusion \\
Cooling Air Cooling & No & No & No & No & No \\
SCR & Yes & None & None & Yes & None \\
Firing Temperature (F) & 2500 & 2500 & 2500 & 2550 & 2400 \\
NOx (ppmvd @ 15\%O2) & 9 & 9 & 9 & 9 & 15 \\
\hline
\end{tabular}

Table 9 - Conceptual Design Option Results for Cases 10 - 14

\begin{tabular}{|lcccccc|}
\hline \multicolumn{7}{c|}{ Gas Turbine and Systems Configurations } \\
\hline Parameters & Case 10 & Case 11 & Case 12 & Case 13 & Case 14 \\
\hline \hline ASU Type & EP & LP & EP & EP & EP \\
Air Integration & None & None & Partial & Full & Partial, 50\% \\
Diluent Type & N2 Inj + Fuel & Fuel Sat & N2 Sat + Fuel & N2 Sat + Fuel & N2 Sat + Fuel \\
Fuel Temperature & Sat & 533 & 533 & 600 & 600 & Sat \\
Compressor & Reduced FA+e & FA+e & New FB & New FB & New FB \\
Combustor Type & Diffusion & DLN & DLN & DLN & DLN \\
Cooling Air Cooling & No & No & No & No & No \\
SCR & None & None & None & None & None \\
Firing Temperature (F) & 2400 & 2400 & 2550 & 2550 & 2600 \\
NOx (ppmvd @ 15\%O2) & 15 & 15 & 9 & 9 & 9 \\
\hline
\end{tabular}


Table 10 - Conceptual Design Option Results for Cases 15 - 18

\begin{tabular}{|lcccc|}
\hline \multicolumn{4}{c}{ Gas Turbine and Systems Configurations } \\
\hline Parameters & Case 15 & Case 16 & Case 17 & Case 18 \\
\hline ASU Type & EP & EP & EP & EP \\
Air Integration & Partial, 50\% & Full & Partial & Partial \\
Diluent Type & N2 + Fuel Sat & N2 Sat + Fuel & N2 Sat + Fuel & N2 Sat + Fuel \\
Fuel Temperature & 600 & 600 & Sat & Sat \\
Compressor & New FB & New FB & Reduced FA+e & Reduced FB \\
Combustor Type & DLN & DLN & Diffusion & Diffusion \\
Cooling Air Cooling & Yes & No & Yes & No \\
SCR & Yes & Yes & None & None \\
Firing Temperature (F) & 2600 & 2650 & 2400 & 2500 \\
NOx (ppmvd @ 15\%O2) & 9 & 9 & 2 & 2 \\
\hline
\end{tabular}

Cases 14 through 16 use higher firing temperature than current FB and reduced cooling by utilizing new CMC materials for turbine first stage nozzles. Case 15 even explores the potential of using external turbine cooling air. Cases 17 and 18 explore Diffusion combustor and new turbine hot gas path design to reach DOE goals of 2 ppm NOx limit without SCR by increasing diluent flow to the limit by saturation of $\mathrm{N} 2$ and fuel.

The 18 options represent reasonable, compatible options, which explore the region of attractive turbine configurations with aim to provide improved performance, increased output, efficiency and reduced NOx emissions for IGCC systems.

\section{Task 4 - Results/Discussion:}

Overview: The integrated IGCC system analysis model developed in Task 3 was used to determine the influence coefficients of vital gas turbine parameters (firing temperature, turbine and compressor efficiency, compressor pressure ratio, cooling flow, fuel and diluent temperature, etc.) on key plant-level performance goals (net plant efficiency, net output, NOx emissions, etc.). The analysis model was utilized to perform IGCC performance trade-off analysis of various gas turbine cycle design options in order to determine which options best meet DOE IGCC Plant Goals. 


\section{Task 4 Discussion:}

Task 4.1: - Determine Gas Turbine Vital Parameters Influence on Plant Level Performance IGCC simulation model was exercised to determine the influence coefficients on four key IGCC plant level performance parameters namely, net efficiency, net output, gas turbine output and NOx emissions of the 11 selected gas turbine cycle parameters.

Influence coefficients, as shown in Table 11, are defined as the relative change in IGCC plant performance parameter such as IGCC net efficiency for an incremental change in gas turbine cycle parameter, such as Firing temperature or relative slope value, (DY/Y)/(DX/X), where X and Y refer to values for Baseline IGCC system.

Table 11: Gas Turbine Cycle Influence Coefficients on IGCC Performance

\begin{tabular}{|l|l|l|l|l|}
\hline Turbine Cycle Parameter & IGCC Net Eff & IGCC Net kW & GT Output & NOx \\
\hline Firing Temperature & 0.584 & 3.113 & 2.948 & 2.604 \\
\hline Turbine Isen Efficiency \% & 0.784 & 0.784 & 2.070 & 0.000 \\
\hline Compressor Isen Efficiency \% & 0.252 & 0.669 & 0.937 & 0.130 \\
\hline Compressor Air Flow & -0.026 & 0.970 & 1.007 & 0.000 \\
\hline Compressor Pressure Ratio & -0.048 & -0.361 & -0.144 & 0.910 \\
\hline Turbine Cooling Flow & -0.045 & -0.180 & -0.208 & 0.525 \\
\hline Combustor DP/P & -0.010 & -0.009 & -0.026 & 0.207 \\
\hline Nitrogen Dilluent Flow & 0.020 & 0.192 & 0.294 & -3.869 \\
\hline Diluent Supply Temperature & 0.063 & -0.055 & -0.058 & 0.715 \\
\hline Syngas Supply Temperature & 0.030 & -0.110 & -0.078 & 0.840 \\
\hline Air Extraction & -0.003 & -0.087 & -0.154 & 0.044 \\
\hline \hline
\end{tabular}


Results show that gas turbine Firing Temperature, Turbine \& Compressor Efficiency, Diluent Supply Temperature, Compressor Pressure Ratio and Cooling Flows have the maximum impact on IGCC net efficiency.

IGCC net output was most impacted by Firing Temperature, Compressor Inlet Air Flow, Turbine \& Compressor Efficiency, Compressor Pressure Ratio and Dilution Flow respectively.

Gas Turbine Output was most impacted by Firing Temperature, Turbine \& Compressor Efficiency and Compressor Inlet Air respectively.

Combustion Technology (Diffusion or Premix), Diluent flow, Firing Temperature and Compressor Pressure Ratio have the most impact on NOx Emissions.

The analysis results indicate that IGCC performance is most influenced by gas turbine internal design parameters such as Firing Temperature, Turbine and Compressor geometry, Combustion and Cooling technology. IGCC cycle integration parameters such as Fuel and Diluent Flow and supply conditions have secondary impact except for NOx emissions.

\section{Task 4.2: - Perform Design Trade-off Analysis}

Eighteen new gas turbine cycle designs were selected in Task 3.3 for conducting IGCC plant performance trade-off studies. These studies utilized IGCC System Performance Simulation Model developed in task 3.2. Tables 12 through 14 show IGCC summary performance of these cases. Results indicate that IGCC efficiency gains up to 2.8 pts, from $40.5 \%$ to $43.3 \%$ and IGCC net output gains up to $35 \%$ are possible due to improvements in gas turbine technology alone with single digit NOx emission levels. 
Table 12: IGCC Summary Performance of Gas Turbine Cycle Design Cases 1 thru 6

\begin{tabular}{|c|c|c|c|c|c|c|c|}
\hline Stream Description & $\underline{\text { Units }}$ & Case 01 & Case 02 & Case 03 & Case 04 & Case 05 & Case 06 \\
\hline $\begin{array}{l}\text { CC Power } \\
\text { Aux Power }\end{array}$ & $\mathrm{kW}$ & 750100 & 759800 & 600500 & 624000 & 608700 & 760100 \\
\hline ASU & $\mathrm{kW}$ & 100400 & 81700 & 33700 & 54300 & 48900 & 81700 \\
\hline Gasification & $\mathrm{kW}$ & 14500 & 13500 & 11500 & 11900 & 11300 & 13500 \\
\hline CC Plant & $\mathrm{kW}$ & 12200 & 12500 & 11000 & 9700 & 10700 & 12500 \\
\hline Net Power & $\mathrm{kW}$ & 623000 & 652100 & 544300 & 548100 & 537800 & 652400 \\
\hline Feed Q (HHV) & MMbtu/hr & 5080 & 5212 & 4424 & 4587 & 4347 & 5213 \\
\hline Net Heat Rate (HHV) & Btu/kW-hr & 8154 & 7993 & 8127 & 8369 & 8083 & 7990 \\
\hline Net Efficiency (HHV) & & $41.88 \%$ & $42.73 \%$ & $42.02 \%$ & $40.81 \%$ & $42.25 \%$ & $42.74 \%$ \\
\hline Net Heat Rate (LHV) & Btu/kW-hr & 7876 & 7721 & 7850 & 8084 & 7808 & 7718 \\
\hline Net Efficiency (LHV) & & $43.36 \%$ & $44.23 \%$ & $43.51 \%$ & $42.25 \%$ & $43.74 \%$ & $44.25 \%$ \\
\hline GT Parameters & Units & & & & & & \\
\hline Combustor Type & & Diffusion & Diffusion & Diffusion & Diffusion & Premix & Premix \\
\hline Tfire & $F$ & 2400 & 2500 & 2500 & 2500 & 2500 & 2500 \\
\hline Texh & $\mathrm{F}$ & 1100 & 1200 & 1200 & 1200 & 1200 & 1200 \\
\hline Stack NOx & ppmvd@15\% O2 & 15 & 9 & 15 & 9 & 9 & 9 \\
\hline GT Spec Output & $\mathrm{kW}-\mathrm{s} / \mathrm{lb}$ & 254.4 & 255.0 & 189.0 & 263.5 & 209.9 & 255.2 \\
\hline IGCC Spec Output & $\mathrm{kW}-\mathrm{s} / \mathrm{lb}$ & 165.3 & 173.0 & 144.4 & 171.3 & 151.6 & 173.1 \\
\hline CC LHV \% Eff & & $65.84 \%$ & $65.04 \%$ & $60.46 \%$ & $60.70 \%$ & $62.35 \%$ & $65.06 \%$ \\
\hline Exh Dp & in $\mathrm{H} 2 \mathrm{O}$ & -15.0 & -15.9 & -15.9 & -16.1 & -16.1 & -15.0 \\
\hline
\end{tabular}

Table 13: IGCC Summary Performance of Gas Turbine Cycle Design Cases 7 thru 12

\begin{tabular}{|c|c|c|c|c|c|c|c|}
\hline Stream Description & $\underline{\text { Units }}$ & Case 07 & Case 08 & Case 09 & Case 10 & Case 11 & Case 12 \\
\hline CC Power & $\mathrm{kW}$ & 875500 & 605500 & 598600 & 665400 & 611200 & 752900 \\
\hline \multicolumn{8}{|l|}{ Aux Power } \\
\hline ASU & $\mathrm{kW}$ & 122300 & 30200 & 40900 & 96200 & 49400 & 79800 \\
\hline Gasification & $\mathrm{kW}$ & 15000 & 11500 & 11400 & 11700 & 11400 & 13300 \\
\hline CC Plant & $\mathrm{kW}$ & 13600 & 11100 & 11000 & 10900 & 10800 & 12200 \\
\hline Net Power & $\mathrm{kW}$ & 724600 & 552700 & 535300 & 546600 & 539600 & 647600 \\
\hline Feed Q (HHV) & MMbtu/hr & 5782 & 4437 & 4388 & 4501 & 4396 & 5140 \\
\hline Net Heat Rate (HHV) & Btu/kW-hr & 7980 & 8027 & 8197 & 8235 & 8147 & 7936 \\
\hline Net Efficiency (HHV) & & $42.80 \%$ & $42.55 \%$ & $41.66 \%$ & $41.47 \%$ & $41.92 \%$ & $43.03 \%$ \\
\hline Net Heat Rate (LHV) & Btu/kW-hr & 7708 & 7754 & 7918 & 7954 & 7870 & 7666 \\
\hline Net Efficiency (LHV) & & $44.31 \%$ & $44.05 \%$ & $43.13 \%$ & $42.93 \%$ & $43.40 \%$ & $44.55 \%$ \\
\hline GT Parameters & Units & & & & & & \\
\hline Combustor Type & & Premix & Premix & Diffusion & Diffusion & Premix & Premix \\
\hline Tfire & $F$ & 2500 & 2550 & 2400 & 2400 & 2400 & 2550 \\
\hline Texh & $\mathrm{F}$ & 1200 & 1200 & 1100 & 1100 & 1100 & 1200 \\
\hline Stack NOx & ppmvd@15\% O2 & 9 & 9 & 15 & 15 & 15 & 9 \\
\hline GT Spec Output & kW-s/lb & 303.0 & 191.5 & 189.9 & 266.0 & 198.5 & 255.0 \\
\hline IGCC Spec Output & $\mathrm{kW}-\mathrm{s} / \mathrm{lb}$ & 192.3 & 146.7 & 142.0 & 170.2 & 143.2 & 171.8 \\
\hline CC LHV \% Eff & & $67.62 \%$ & $60.78 \%$ & $60.70 \%$ & $65.90 \%$ & $61.85 \%$ & $65.44 \%$ \\
\hline Exh Dp & in $\mathrm{H} 2 \mathrm{O}$ & -15.0 & -16.1 & -15.0 & -15.0 & -15.0 & -15.0 \\
\hline
\end{tabular}


Table 14: IGCC Summary Performance of Gas Turbine Cycle Design Cases 13 thru 18

\begin{tabular}{|c|c|c|c|c|c|c|c|}
\hline Stream Description & Units & Case 13 & $\underline{\text { Case } 14}$ & $\underline{\text { Case } 15}$ & Case 16 & Case 17 & $\underline{\text { Case } 18}$ \\
\hline $\begin{array}{l}\text { CC Power } \\
\text { Aux Power }\end{array}$ & $\mathrm{kW}$ & 777700 & 784800 & 773500 & 700000 & 728700 & 691900 \\
\hline ASU & kW & 55500 & 86100 & 83000 & 50700 & 78700 & 74700 \\
\hline Gasification & kW & 14300 & 13900 & 13600 & 12800 & 13500 & 12700 \\
\hline CC Plant & kW & 13200 & 12600 & 12700 & 12000 & 10700 & 10100 \\
\hline Net Power & $\mathrm{kW}$ & 694700 & 672200 & 664200 & 624500 & 625800 & 594400 \\
\hline Feed Q (HHV) & MMbtu/hr & 5537 & 5352 & 5239 & 4930 & 5213 & 4883 \\
\hline Net Heat Rate (HHV) & Btu/kW-hr & 7970 & 7962 & 7888 & 7894 & 8329 & 8215 \\
\hline Net Efficiency (HHV) & & $42.85 \%$ & $42.89 \%$ & $43.29 \%$ & $43.26 \%$ & $41.00 \%$ & $41.57 \%$ \\
\hline Net Heat Rate (LHV) & Btu/kW-hr & 7698 & 7691 & 7620 & 7625 & 8046 & 7935 \\
\hline Net Efficiency (LHV) & & $44.36 \%$ & $44.41 \%$ & $44.82 \%$ & $44.79 \%$ & $42.45 \%$ & $43.04 \%$ \\
\hline GT Parameters & Units & & & & & & \\
\hline Combustor Type & & Premix & Premix & Premix & Premix & Diffusion & Diffusion \\
\hline Tfire & $\mathrm{F}$ & 2550 & 2600 & 2600 & 2650 & 2400 & 2500 \\
\hline Texh & $\mathrm{F}$ & 1200 & 1200 & 1200 & 1200 & 1100 & 1200 \\
\hline Stack NOx & ppmvd@15\% O2 & 9 & 9 & 9 & 9 & 2 & 2 \\
\hline GT Spec Output & $\mathrm{kW}-\mathrm{s} / \mathrm{lb}$ & 215.0 & 267.8 & 260.9 & 229.4 & 300.3 & 329.1 \\
\hline IGCC Spec Output & $\mathrm{kW}-\mathrm{s} / \mathrm{lb}$ & 155.3 & 178.4 & 176.2 & 165.7 & 186.5 & 203.8 \\
\hline CC LHV \% Eff & & $62.70 \%$ & $65.56 \%$ & $65.98 \%$ & $63.42 \%$ & $62.38 \%$ & $63.29 \%$ \\
\hline Exh Dp & in $\mathrm{H} 2 \mathrm{O}$ & -15.0 & -15.0 & -16.1 & -16.1 & -15.0 & -15.0 \\
\hline
\end{tabular}




\section{Task 5 - Results/Discussion:}

Overview: Various GT cycle designs were examined utilizing the performance results to select the most promising candidate cycle concepts. The 3 most promising GT candidates are recommended on the basis of their merit on IGCC Efficiency, IGCC Net Output, GT Specific Output and NOx Emissions. For near term (2006): the recommended GT cycle design should have a $2400 \mathrm{~F}$ class firing temperature, base class compressor pressure ratio (CPR), diffusion combustor and integrated air extraction; for midterm (2008): a 2500F class firing temperature, base class CPR, diffusion combustor, and integrated air extraction; and for long term (2010): a $2600 \mathrm{~F}$ class firing temperature, increased CPR, and further combustion and hot gas path technology enhancements. A roadmap of turbine technology development leading to DOE IGCC efficiency goal of $50 \%$, less than $\$ 1000 / \mathrm{kw}$ cost and NOx emissions less than $3 \mathrm{ppm}$ is presented.

\section{Task 5 - Discussion:}

Results of the Trade-Off Analysis utilizing 18 Conceptual Design Options have been used to produce the most promising candidate GT Cycle Design Concepts which best meet DOE goals for this study. The GT Cycle Design Concepts were analyzed relative to Overall IGCC

Efficiency, IGCC Specific Power, GT Specific Power, NOx Emissions and shown in Figure 8.

\section{IGCC Plant Performance Vs GT Options}

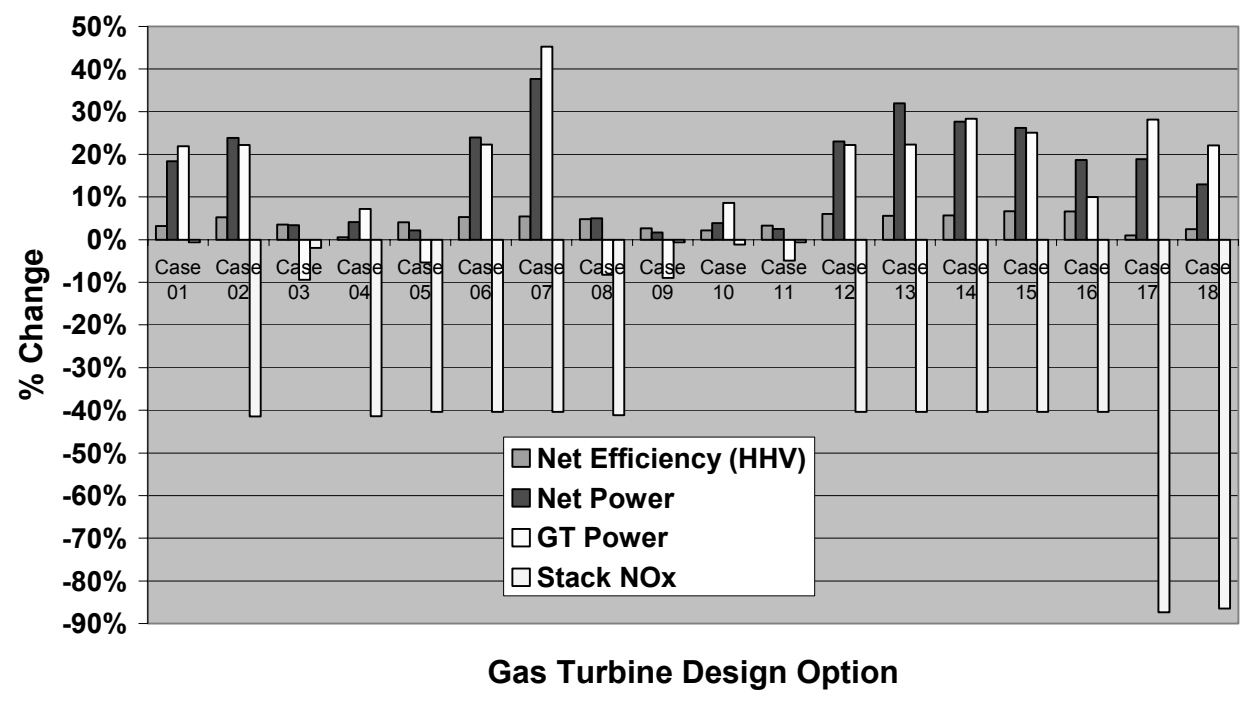

Figure 8: IGCC Plant Performance of GT Design Options

One way to select gas turbine is to analyze the IGCC Efficiency against GT Specific Output as shown in Figure 9 for various GT options. The higher the IGCC efficiency and GT Specific Output, the design option will result in higher cost effective machine. 
IGCC Net Efficiency (HHV) Vs GT Specific Output \%

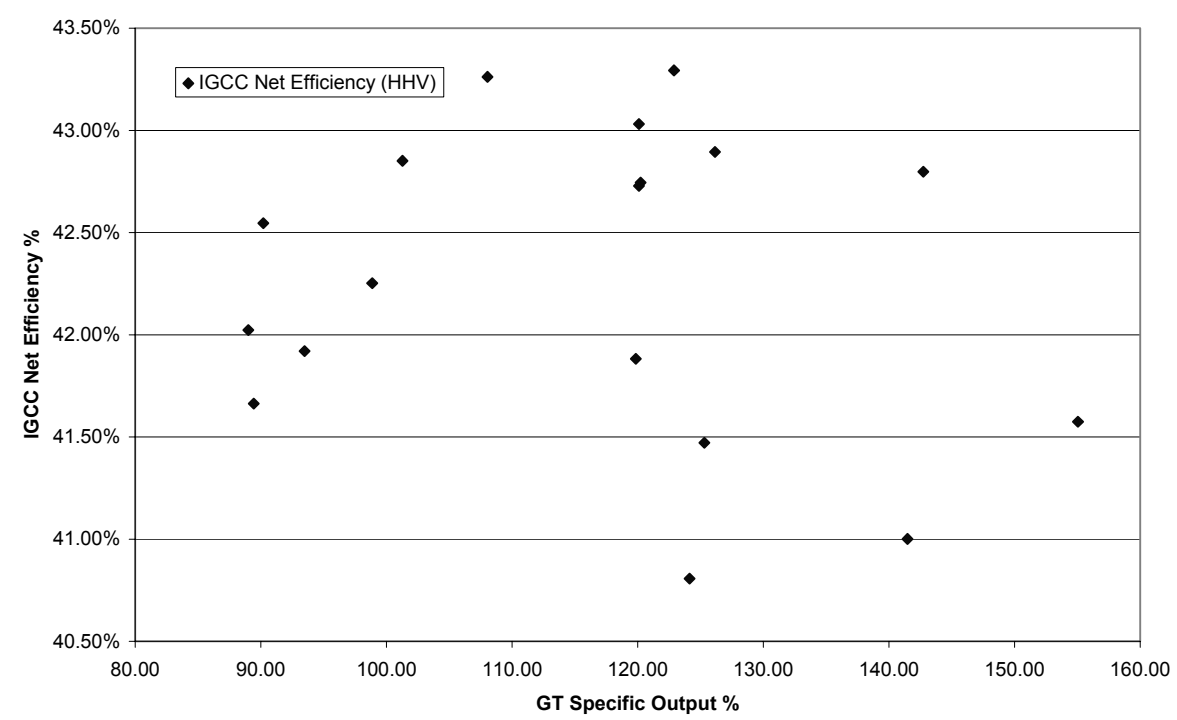

Figure 9: IGCC Net Efficiency vs. GT Specific Output for various GT options

Another way to select gas turbine is to analyze the IGCC Specific Output against GT Specific Output as shown in Figure 10 for various GT options. The higher the IGCC specific output and GT Specific Output, the design option will result in higher cost effective machine.

IGCC Spec Output \% VS Gas Turbine Specific Output \%

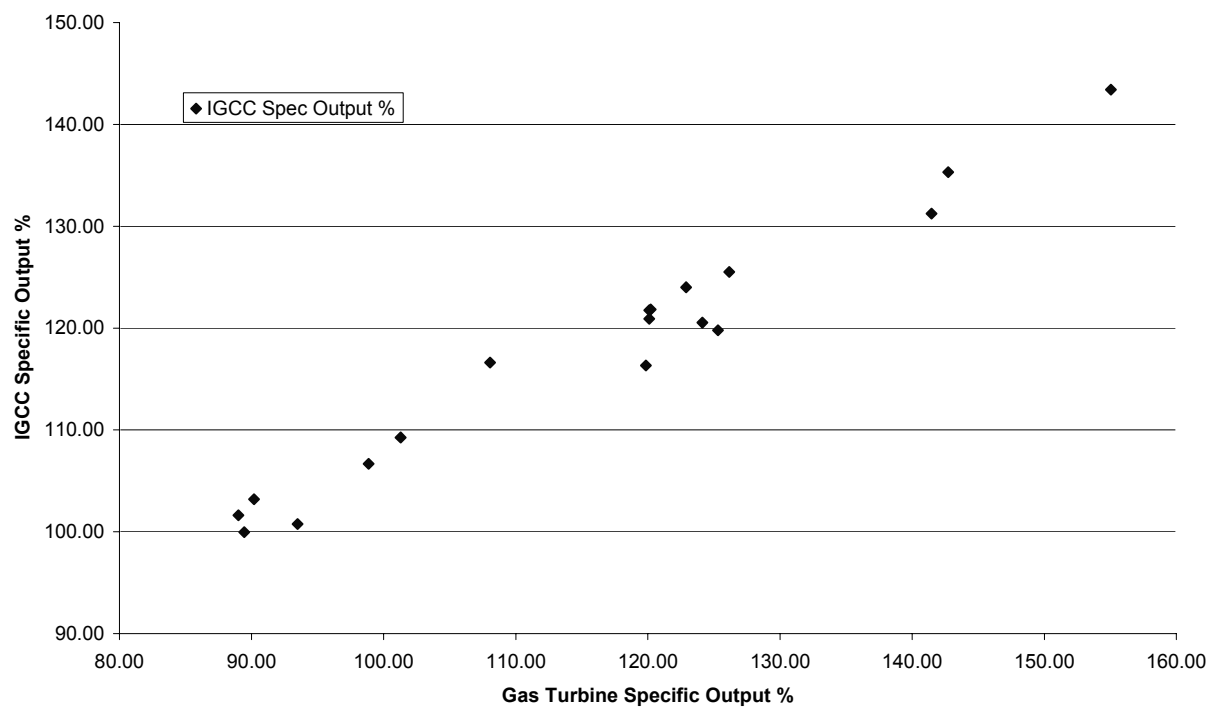

Figure 10: IGCC Specific Output vs. GT Specific Output for various GT options 
When IGCC Efficiency and IGCC Output have equal importance, the GT options can be selected as the option, which would give both of these higher values as shown in Figure 11.

\section{Optimized IGCC Cycle Selection}

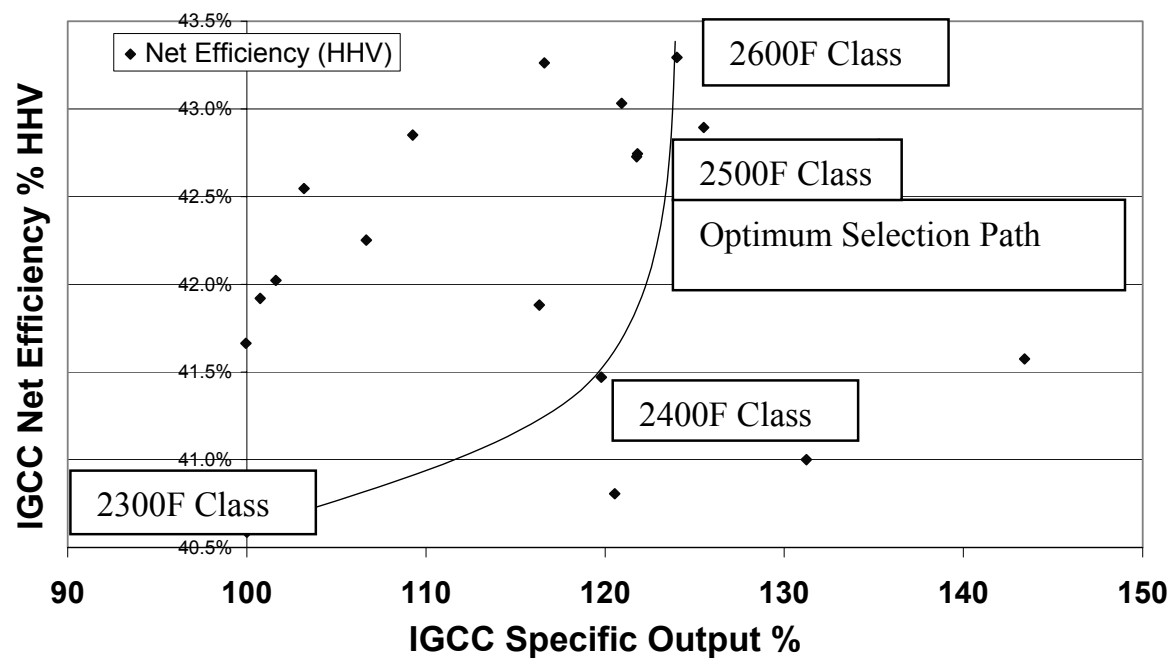

Figure 11: IGCC Net Efficiency vs. IGCC Specific Output for various GT options

As GT Cycle Firing temperature increases from 2300F to 2600F, IGCC plant efficiency increases and IGCC Specific Output also increases. An optimum GT cycle selection path is shown in Figure 11, based on increased GT technology development required.

Turbine Technology Development Roadmap: A roadmap of gas turbine technology and development is required to advance beyond today's state-of-the art performance, economics, and emissions for coal based IGCC power plants. Today's IGCC technology delivers 40\% efficiency, low double-digit NOx, and competitive COE. Future targets and technologies have been proposed to reach 50\% HHV efficiency, with lower capital cost and COE performance, while isolating $\mathrm{CO} 2$ and producing less than 3ppm NOx. The recommended technology roadmap is shown in Figure 12.

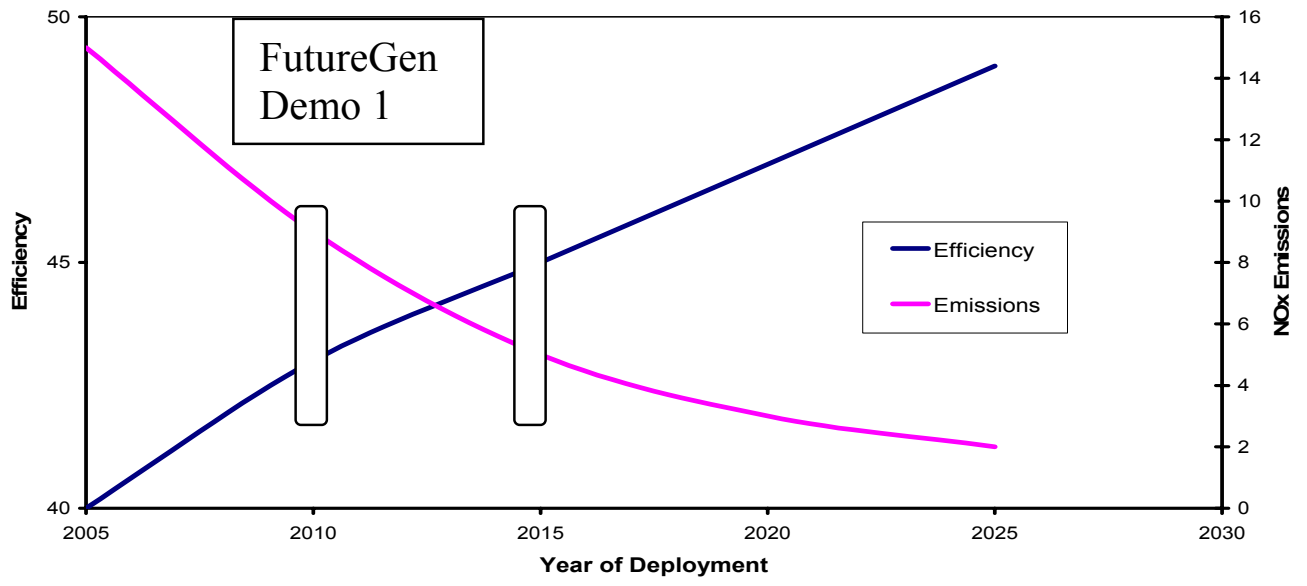

Figure 12: Turbine Technology Roadmap for future coal-based IGCC 


\section{$\underline{\text { Near-Term Developments }}$}

Near-term, high efficiency can be accomplished by improving GT cycle technology through conventional means of increased firing temperature and pressure ratio, and through advanced cycle integration concepts. Increased firing temperature, $\mathrm{CO} 2$ sequestration, and lower NOx targets all cause additional demands on combustion and turbine technologies related to highhydrogen combustion and turbine durability. These two challenges are common to the next generations of high technology and very low emissions turbine power plants envisioned by power generation researchers and industry.

High efficiency for the 7FB IGCC will be achieved by performing a system optimization of the integrated cycle, by analyzing the impact of technologies and design choices on performance, reliability, and Cost of Electricity. Further advances in turbine cooling and materials technology will provide significant improvements toward performance and economic objectives: such as allowing increased firing temperature at a given $\mathrm{NOx}$, and reducing turbine cooling flows. Advances are needed in the state-of-art combustor from a diffusion-flame to pre-mix fuel nozzle, improving NOx characteristics on syngas and carbon free high Hydrogen fuels. Current IGCC gas turbine practice involves injection of dilution gas, typically nitrogen or steam, into a diffusion-flame combustor in order to mitigate NOx emissions. As NOx limits are reduced to the 2ppm DOE goal, large amounts of steam will be required for diluent, as nitrogen will not be adequate. Without corresponding combustor improvements, the NOx is most effectively reduced by injecting steam, reducing turbine life by increasing water content and heat transfer. Other methods of improving high $\mathrm{H} 2$ combustion performance such as Trapped vortex/ Rich Catalyst/ Exhaust gas Recirculation may also be required to achieve less than 3 ppm NOx emission goals. Ceramic Matrix Composite (CMC) components will provide additional performance advantages in this environment. Not only do CMCs require less cooling than metallic parts in current turbine environments, they will consume less incremental cooling as gas path heat capacity increases from higher moisture and higher firing temperature.

\section{$\underline{\text { Long-Term Developments }}$}

Long-term coal based IGCC cycles will optimize around improved technologies in all areas of combustion, turbine, air separation unit (ASU), CO2 separation, gasifier, and process island technologies.

There is potential for additional benefit through increased cycle integration using components such as intercoolers, recuperators, and by incorporating novel ideas such as exhaust gas recirculation, reheat combustion, and variable inlet oxygen content. These concepts will present new challenges with regard to risk, costs, startup and transient performance, control and flexibility criteria.

The roadmap shows FutureGen demos in 2010 and 2015. The 2010 configuration would include diffusion-flame combustion with diluent injection and an SCR, using the 7FB optimized for near-term market needs and with the best available injector technologies. The 2015 demo would include features of the advanced combustion systems, with better performance while running on higher hydrogen content. Other aspects of the test would include advanced HGP material and 
cooling strategies. The cycle efficiency of these units would demonstrate both progress along the efficiency and emissions roadmap, but also the enabling capabilities required for higher hydrogen turbines proposed for longer-range development.

\section{Task 6 - Results/Discussion:}

Overview: High Hydrogen fueled Gas turbine performance model was created for an integrated IGCC with newly created models of variable Carbon capture and removal subsystems. IGCC Performance impact of $85 \%$ and $88 \%$ CO2 removal levels were analyzed for $2300 \mathrm{~F}$ class and $2500 \mathrm{~F}$ class gas turbines. Performance penalty as compared to gas turbine designs without carbon capture are studied and reported.

\section{Task 6 - Discussion:}

Performance analysis modeling was completed of a high Hydrogen fueled gas turbine based Oxygen blown IGCC power plant using a conventional system of carbon removal from syngas. The system modeled consists of conversion of carbon monoxide in the moisturized syngas to carbon dioxide and hydrogen by utilizing shift catalyst, and later removal of carbon dioxide by Selexol solvent in Acid Gas Removal unit, as shown in Figure 13 below:

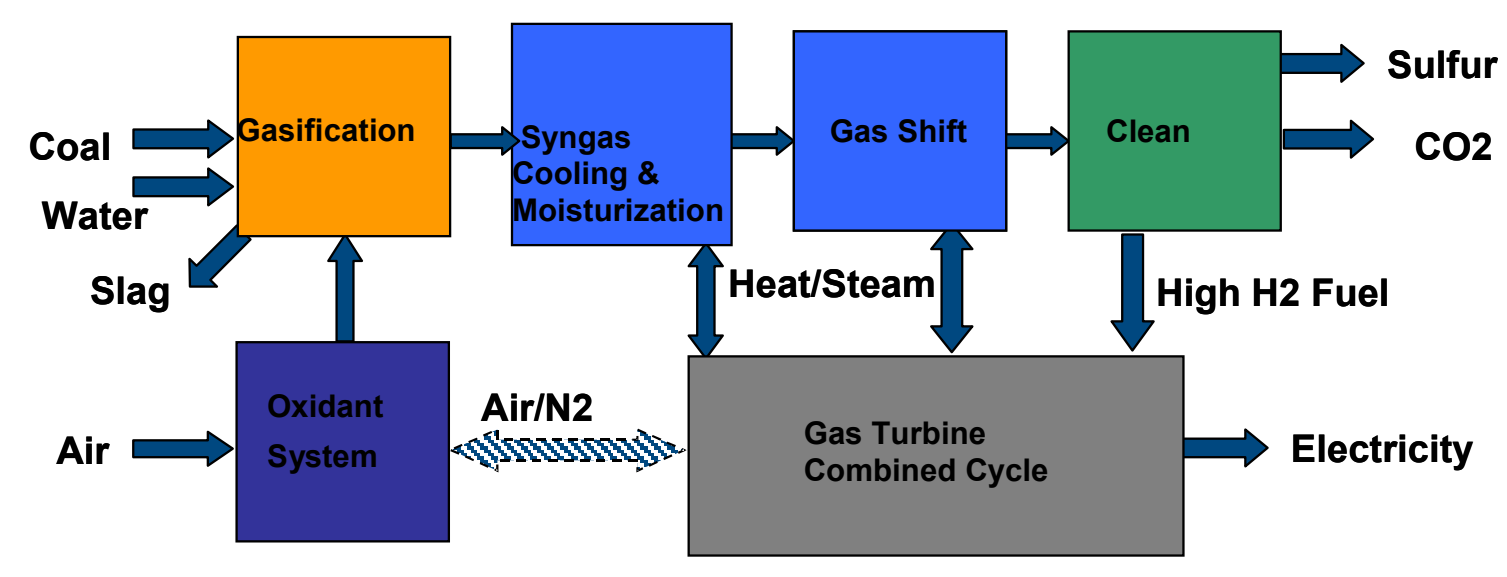

Figure 13: Simplified IGCC Cycle with CO2 Capture

The performance penalty for carbon removal in the IGCC plant model was minimized by first moisturizing and shifting in the low temperature sour gas shift reactors operated at $400 \mathrm{~F}$ and subsequently cooling of the syngas in two stages. Carbon dioxide recovery in the model was varied by changing the number of separation columns, amount and temperature of Selexol absorbent in the Acid Gas Removal Unit. Cleaned syngas fuel to gas turbine contained mostly hydrogen together with unconverted carbon monoxide, unremoved carbon dioxide and methane. Figure 14 shows \% of total input carbon removal by varying CO2 removal rate and level of shift. It was determined that carbon removal rate of greater than $88 \%$ was not practical due to 
significant amount of methane (about $6 \%$ of dry syngas and $7 \%$ of carbon content) in the fuel to gas turbine, which could not be removed in the gas shift or in Acid Gas removal process.

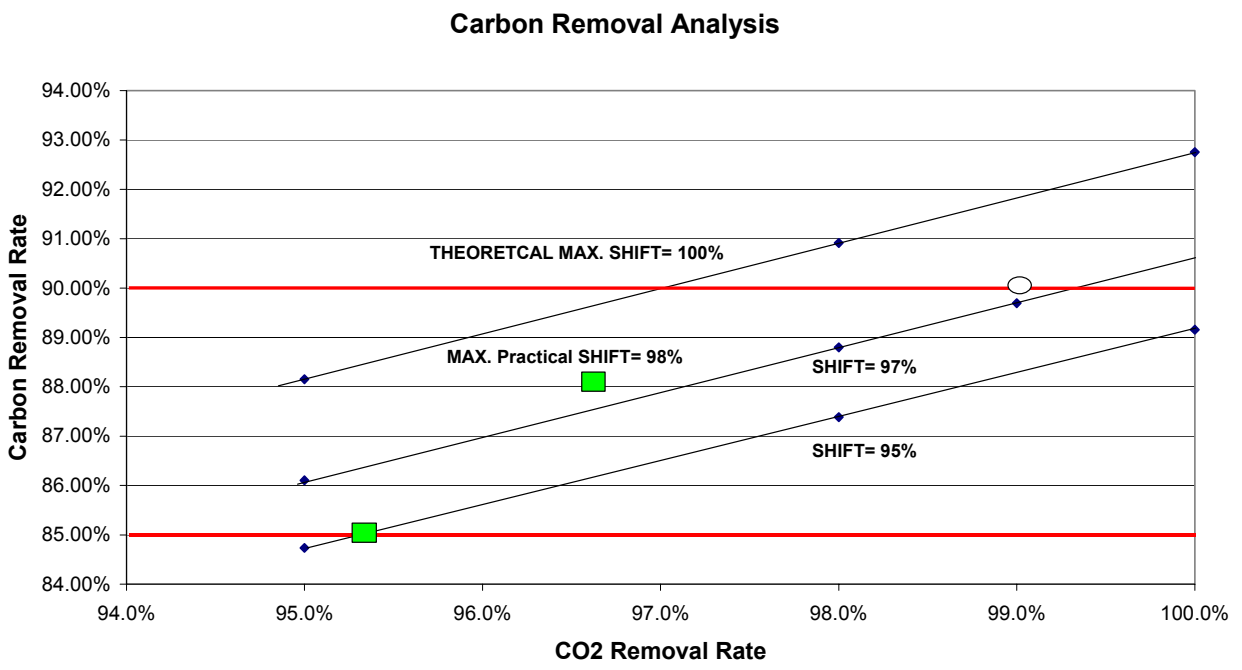

Figure 14: Carbon Removal From O2 Blown IGCC Power Plant

Figure 15 shows the relationship between $\%$ gas shift and $\%$ moisturization of syngas. It is clear that increasing moisturization above $45 \%$ provides limited improvement in gas shift. A practical upper limit of conventional gas shift appears to be $98 \%$.

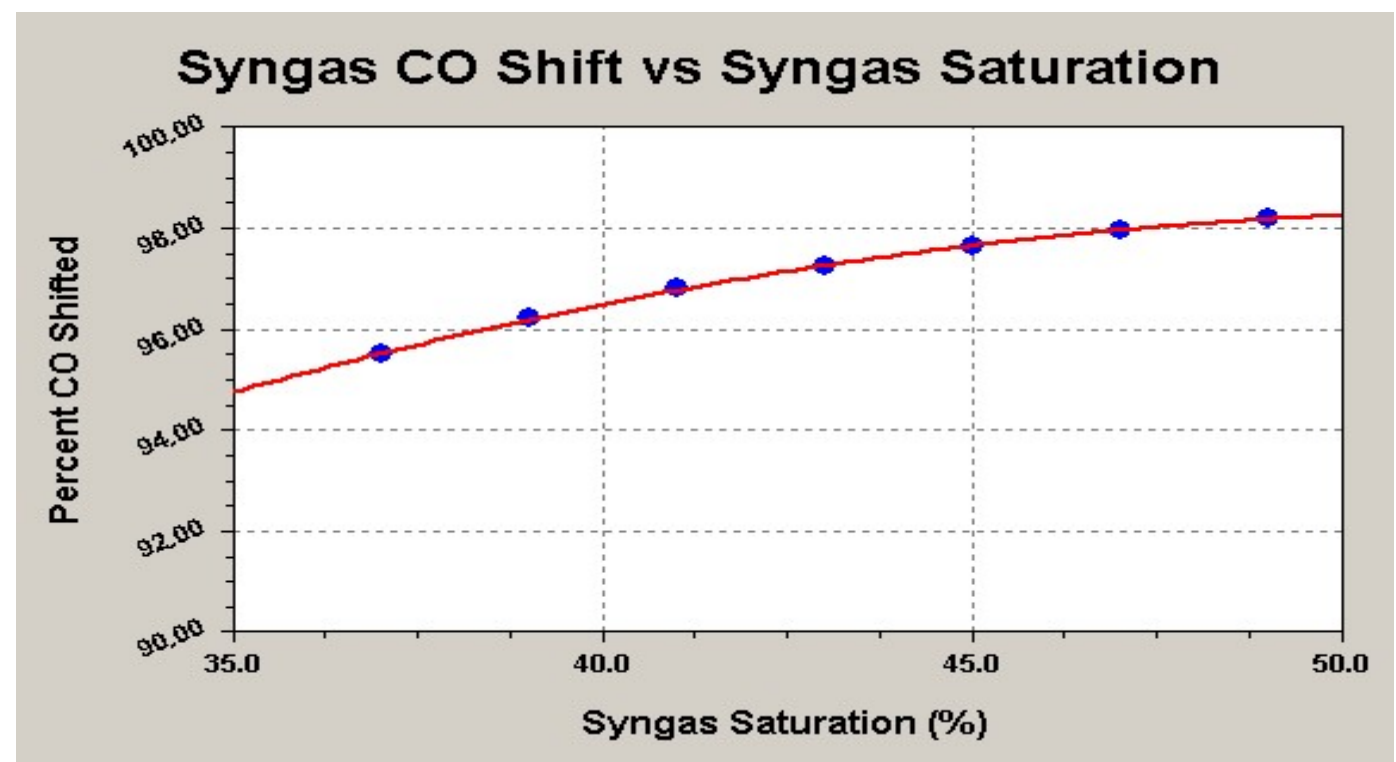

Figure 15: Shift conversion rate vs. \% Saturation of Syngas 
Figure 16 shows increase in auxiliary power required with increase in desired carbon dioxide removal rate for Selexol solvent. The auxiliary power consumption and the associated cost of AGR equipment increases linearly with carbon dioxide removal rate up to a level of $90 \%$. This technology has an upper limit of $97 \%$ on carbon dioxide removal level, based on a practical limit on the number of carbon dioxide removal columns (assumed to be three). It is recommended that a different carbon dioxide removal technology such as cryogenic $\mathrm{CO} 2$ separation or membrane be used beyond a carbon dioxide removal level of $97 \%$.

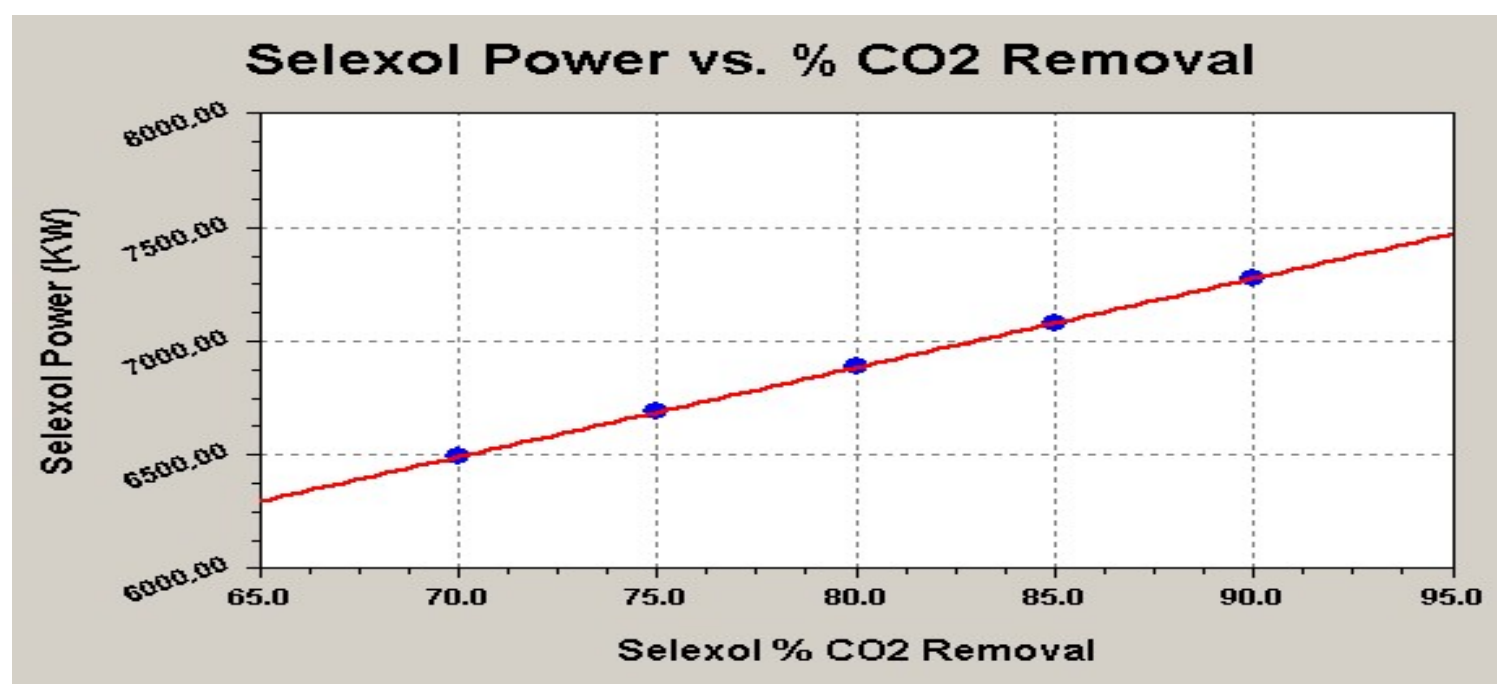

Figure 16: Auxiliary Power Consumed vs. \% CO2 Removal in AGR Unit

The detailed IGCC model configuration with all major streams modified to model a 207FA+e and 207FB based IGCC plants and incorporating additional changes for variable Carbon capture and removal is shown in Figure 17. 


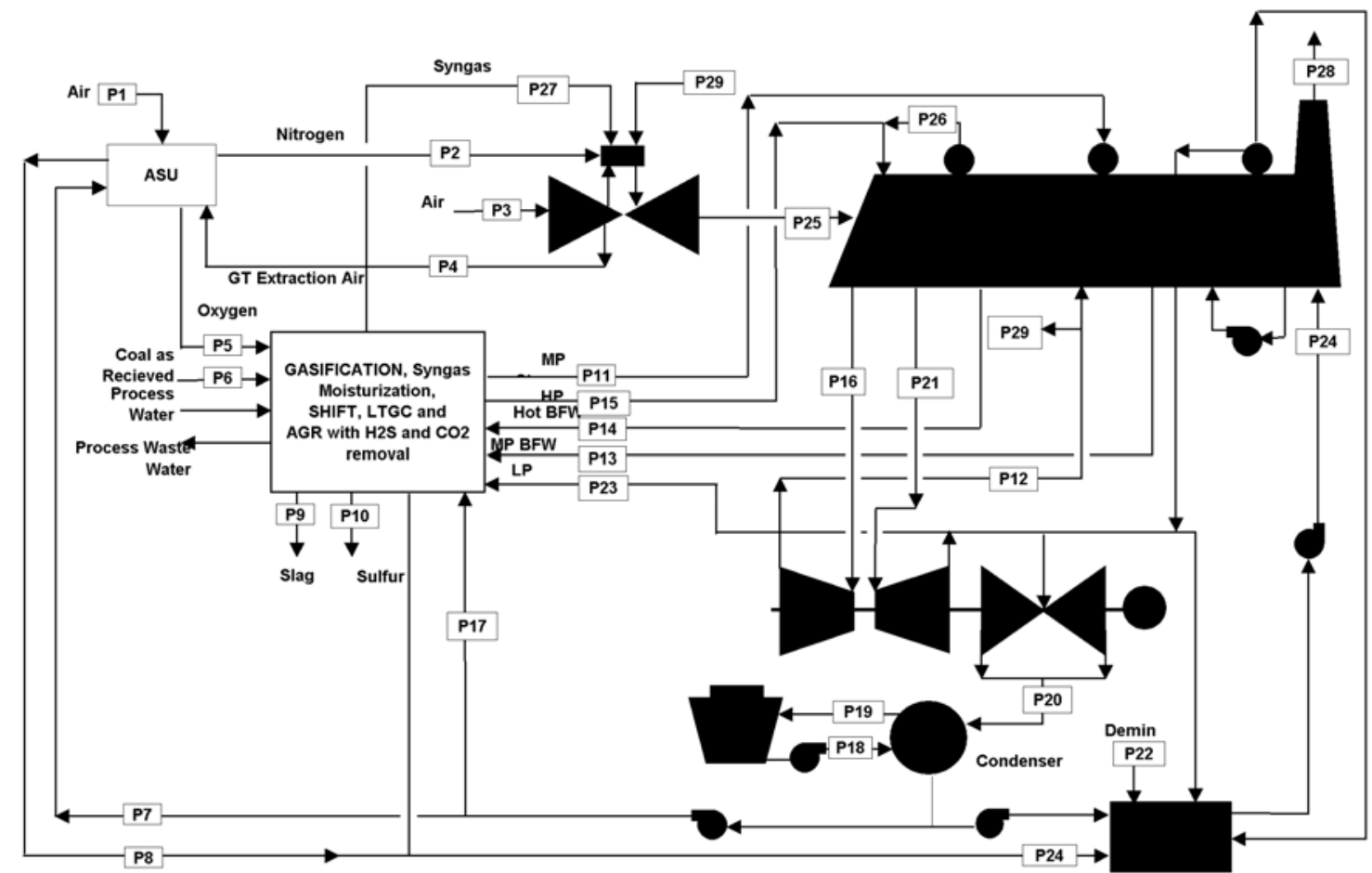

Figure 17: IGCC Performance model incorporating variable Carbon capture and removal

The results of gas turbine fuel gas analysis for carbon capture levels of $85 \%$ and $88 \%$ for the IGCC plant are shown in Table 15 below. It should be noted that the gas turbine fuel hydrogen content has increased from about $26 \%$ by volume for no Carbon Capture case to greater than $71 \%$ for Carbon capture cases, while fuel Carbon monoxide and Carbon dioxide content by volume has reduced from roughly $44 \%$ and $10 \%$ for no Carbon Capture cases to about $2 \%$ for Carbon capture cases. However, fuel mass heating value has increased substantially from roughly $4550 \mathrm{Btu} / \mathrm{lb}$ to 12000 to $13000 \mathrm{Btu} / \mathrm{lb}$ resulting in large reduction in gas turbine fuel flow.

\begin{tabular}{|c|c|c|}
\hline \multirow[t]{2}{*}{ Syngas Component } & \multicolumn{2}{|c|}{ Volume \% } \\
\hline & $85 \%$ Carbon Conversion & $88 \%$ Carbon Conversion \\
\hline $\mathrm{H}_{2}$ & 71.34 & 73.16 \\
\hline $\mathrm{CO}$ & 2.04 & 1.25 \\
\hline $\mathrm{CH}_{4}$ & 4.44 & 4.50 \\
\hline $\mathrm{CO}_{2}$ & 2.92 & 1.80 \\
\hline $\mathbf{N}_{2}$ & 1.15 & 1.17 \\
\hline $\mathrm{Ar}$ & 1.11 & 1.12 \\
\hline $\mathrm{H}_{2} \mathrm{O}$ & 17.00 & 17.00 \\
\hline Total S (ppm) & 20.6 & 20.7 \\
\hline Heating Value Btu/Lb & 11780 & 13010 \\
\hline
\end{tabular}

Table 15: Gas Turbine Fuel Composition for $85 \%$ and $88 \%$ Carbon removal 
IGCC performance summary of the four gas turbine cycle design cases with $85 \%$ and $88 \%$ Carbon removal and $2300 \mathrm{~F}$ and $2500 \mathrm{~F}$ class firing temperature cases is presented in Table 16. With most of the carbon removed from the fuel, its heating value has increased by a factor of three resulting in a fuel flow decrease by the same order. This results in large reduction of specific output of both the gas turbine and net IGCC power plant. Similarly, energy losses due to saturation of syngas, resulting chemical shift of Carbon monoxide to Carbon dioxide and Hydrogen, and auxiliary power required to capture and remove carbon dioxide all result in reduced net IGCC efficiency.

The results show larger IGCC performance penalty for gas turbine designs with higher firing temperature and higher Carbon removal. A $2500 \mathrm{~F}$ class gas turbine with $85 \% \mathrm{CO} 2$ removal shows a net output penalty of $6.5 \%$ and a net efficiency penalty of $6 \%$ vs. $2300 \mathrm{~F}$ class gas turbine at net output penalty of $4.7 \%$ and a net efficiency penalty of $5.5 \%$, while at $88 \%$ Carbon removal, $2500 \mathrm{~F}$ class gas turbine shows a net output penalty of $8.4 \%$ and a net efficiency penalty $7 \%$ as compared to $2300 \mathrm{~F}$ class gas turbine with net output and net efficiency penalty of $6.4 \%$. 


\begin{tabular}{|c|c|c|c|c|c|}
\hline Description & Units & $\frac{\text { Tfire } 2300-}{85 \% \text { Removal }}$ & $\frac{\text { Tfire } 2500-}{85 \% \text { Removal }}$ & $\frac{\text { Tfire } 2300-}{88 \% \text { Removal }}$ & $\frac{\text { Tfire } 2500-}{88 \% \text { Removal }}$ \\
\hline CC Power & $\overline{\mathrm{kW}}$ & 613900 & 741600 & 605800 & 727100 \\
\hline $\begin{array}{c}\text { Aux Power } \\
\text { ASU }\end{array}$ & & & & & \\
\hline $\begin{array}{l}\text { ASU } \\
\text { Gasification }\end{array}$ & $\mathrm{kW}$ & 79800 & 94400 & 80400 & 95300 \\
\hline Gasification & $\mathrm{kW}$ & 21500 & 24800 & 21700 & 24900 \\
\hline CC Plant & kW & 10900 & 12400 & 10800 & 12100 \\
\hline Net Power & kW & 501700 & 610000 & 492900 & 594800 \\
\hline Feed Q (HHV) & MMbtu/hr & 4900 & 5658 & 4920 & 5674 \\
\hline Net Heat Rate (HHV) & Btu/kW-hr & 9768 & 9276 & 9981 & 9539 \\
\hline Net Efficiency (HHV) & & $34.96 \%$ & $36.82 \%$ & $34.22 \%$ & $35.80 \%$ \\
\hline Net Heat Rate (LHV) & Btu/kW-hr & 9435 & 8960 & 9641 & 9214 \\
\hline Net Efficiency (LHV) & & $36.20 \%$ & $38.12 \%$ & $35.42 \%$ & $37.06 \%$ \\
\hline GT Parameters & $\underline{\text { Units }}$ & & & & \\
\hline Combustor Type & & Diffusion & Diffusion & Diffusion & Diffusion \\
\hline Tfire & $F$ & 2300 & 2500 & 2300 & 2500 \\
\hline Texh & F & 1069 & 1133 & 1069 & 1131 \\
\hline Stack NOx & ppmvd@15\% O2 & 12 & 17 & 12 & 18 \\
\hline GT Spec Output & $\mathrm{kW}-\mathrm{s} / \mathrm{lb}$ & 212.7 & 254.9 & 212.8 & 254.7 \\
\hline IGCC Spec Output & $k W-s / l b$ & 135.4 & 161.9 & 133.1 & 157.8 \\
\hline CC LHV \% Eff & & $62.55 \%$ & $65.64 \%$ & $61.74 \%$ & $64.48 \%$ \\
\hline Exh Dp & in $\mathrm{H} 2 \mathrm{O}$ & -15.0 & -15.0 & -15.0 & -15.0 \\
\hline
\end{tabular}

Table 16: IGCC Summary Performance of Gas Turbine Cycle Design Cases with 85 and $88 \%$ Carbon removal 


\section{Conclusions and Recommendations}

\section{Conclusions:}

\section{Task 1 - Overall IGCC Plant Level Requirements Identification:}

Plant level (power island) requirements were identified, and compared with DOE's IGCC Goal of achieving $50 \%$ Net HHV Efficiency and $\$ 1000 / \mathrm{KW}$ by the Year 2008, through use of a Quality Functional Deployment (QFD) Tool. This analysis resulted in the following 7 Gas Turbine System Level Parameters being selected as the most significant for further analysis of IGCC system Requirements at the power island level:

1) Availability

2) Product Cost per kW

3) Efficiency

4) Air Integration Flexibility

5) Syngas Supply Conditions

6) Diluent Supply Conditions

7) Syngas $\mathrm{NO}_{\mathrm{x}}$ Capability

\section{Task 2 - Requirements Prioritization \& Flow-Down to Gas Turbine Subsystem Level}

Gas turbine requirements were identified, analyzed and prioritized relative to achieving plant level goals, and compared with the flowdown of power island goals through use of a Quality Functional Deployment (QFD) Tool. This analysis resulted in the following 11 Gas Turbine Cycle Design Parameters being selected as the most significant for analysis of Baseline and other IGCC system configurations:
1) Firing Temperature
2) Combustor Options
3) Turbine Efficiency
4) Compressor Efficiency
5) Compressor Pressure Ratio
6) Cooling Flows
7) Percent Air Extraction
8) Syngas Supply Temperature
9) Diluent Supply Temperature
10) Compressor Air Flow
11) Diluent Flow

\section{Task 3 - IGCC Conceptual System Analysis}

A Baseline IGCC Plant configuration was chosen, and an integrated IGCC simulation analysis model was constructed to successfully validate the Baseline IGCC Plant Model against published 
performance data. The baseline model was optimized by including air extraction heat recovery and GE steam turbine model with appropriate last stage buckets.

Baseline IGCC based on GE 207FA+e gas turbine combined cycle has net HHV efficiency of $40.5 \%$ and net output nominally of 526 Megawatts at NOx emission level of 15 ppmvd@15\% corrected $\mathrm{O} 2$.

Eighteen Advanced $\mathrm{F}$ technology gas turbine cycle design options were developed to provide performance targets with increased output and/or efficiency with low NOx emissions for IGCC systems by varying the selected system parameters such as Air Integration Method, ASU type, Diluent Method, and Fuel Temperature, as well as gas turbine parameters such as Combustor Type, Hot Gas Path Configuration, Firing Temperature and Target $\mathrm{NO}_{\mathrm{x}}$ Level.

\section{Task 4 - Gas Turbine Cycle Options vs. Requirements Evaluation}

Influence coefficients on four key IGCC plant level performance parameters namely, net efficiency, net output, gas turbine output and NOx emissions of the 11 gas turbine cycle parameters were determined. IGCC net efficiency was most impacted by gas turbine Firing temperature, turbine \& compressor efficiency, diluent supply temperature, compressor pressure ratio and turbine cooling flows. IGCC net output was most impacted by Firing temperature, compressor inlet airflow, turbine \& compressor efficiency, compressor pressure ratio and dilution flow respectively. IGCC Plant NOx emissions were most influenced by gas turbine combustion technology (Diffusion or Premix), Diluent flow, Firing temperature and compressor pressure ratio.

A total of 18 new gas turbine cycle options based on Advanced F technology have been analyzed. Results indicate that IGCC net efficiency HHV gains up to $2.8 \mathrm{pts}$, from $40.5 \%$ to $43.3 \%$ and IGCC net output gains up to $35 \%$ are possible due to improvements in gas turbine technology alone with single digit NOx emission levels.

\section{Task 5 - Gas Turbine Technology Improvement Recommendations}

Various GT cycle designs were examined utilizing the performance results to select the most promising candidate cycle concepts. The 3 most promising GT candidates are recommended on the basis of their merit on IGCC Efficiency, IGCC Net Output, GT Specific Output and NOx Emissions. For near term (2006): the recommended GT cycle design should have a $2400 \mathrm{~F}$ class firing temperature, base class compressor pressure ratio (CPR), diffusion combustor and integrated air extraction; for midterm (2008): a 2500F class firing temperature, base class CPR, diffusion combustor, and integrated air extraction; and for long term (2010): a 2600F class firing temperature, increased CPR, and further combustion and hot gas path technology enhancements.

A Turbine technology roadmap is presented, which will lead to coal based IGCC goals of 50\% in efficiency, less than $\$ 1000 / \mathrm{kW}$ in cost and NOx emissions less than $3 \mathrm{ppm}$. 


\section{Task 6 - Carbon Capture Impact on IGCC Plant Level Performance}

The results show that IGCC performance penalty for gas turbine cycle designs with higher firing temperature and higher Carbon removal is larger than for current gas turbine designs. A $2500 \mathrm{~F}$ class gas turbine with $85 \% \mathrm{CO} 2$ removal shows a net output penalty of $6.5 \%$ and a net efficiency penalty of $6 \%$ vs. $2300 \mathrm{~F}$ class gas turbine at net output penalty of $4.7 \%$ and a net efficiency penalty of $5.5 \%$, while at $88 \%$ Carbon removal, $2500 \mathrm{~F}$ class gas turbine shows a net output penalty of $8.4 \%$ and a net efficiency penalty $7 \%$ as compared to $2300 \mathrm{~F}$ class gas turbine with net output and net efficiency penalty of $6.4 \%$. will be limited to show performance effects of gas turbine for carbon capture level of $85 \%$ to $88 \%$ on this particular gasification process of an IGCC plant.

\section{$\underline{\text { Recommendations }}$}

The 3 most promising GT candidates are recommended on the basis of their merit on IGCC Efficiency, IGCC Net Output, GT Specific Output and NOx Emissions. For near term (2006): the recommended GT cycle design should have a 2400F class firing temperature, base class compressor pressure ratio (CPR), diffusion combustor and integrated air extraction; for midterm (2008): a 2500F class firing temperature, base class CPR, diffusion combustor, and integrated air extraction; and for long term (2010): a 2600F class firing temperature, increased CPR, and further combustion and hot gas path technology enhancements.

High Carbon capture and removal rate $(85 \%$ or higher) results in high Hydrogen content fuel in the gas turbine with significant performance penalty for a coal fired IGCC in terms of its net output and efficiency. Gas turbine cycle designs with higher firing temperatures have larger performance penalty and need further design optimization to reduce the performance loss and cost impact on IGCC power plants. Gas turbine design changes in terms of turbine hot gas path and the cycle design parameters will be required to minimize the reduction in specific output and net efficiency due to high Hydrogen content of the carbon free syngas fuel. 


\section{$\underline{\text { References }}$}

1. Integrating Clean Coal Technologies and Cogeneration Opportunities with Industrial Land Reuse", Nordic Energy of Ashtabula LLC, Department of Energy Program Solicitation No. DE-PS26-02NT41428, August 2002. 


\section{List of Acronyms and Abbreviations}

AGR - Acid Gas Removal sulfur removal sub-system

ASU - Air Separation Unit oxygen plant sub-system

CPR - Compressor Pressure Ratio

EP - Elevated Pressure Air Separation Unit

FB - GE's Advanced Air cooled Turbine

GT - Gas Turbine

HHV - Fuel Higher Heating Value

HGP - Hot Gas Path

HRSG - Heat Recovery Steam Generator

IGCC - Integrated Gasifier Combined Cycle power plant

LP - Low Pressure Air Separation Unit

LTGC - Low Temperature Syngas Cooling Unit

NOx - Gaseous mixture of Nitrogen Oxides

SCR - Selective Catalytic Reduction

QFD - Six Sigma Quality Functional Deployment analysis system 
